\title{
Marine bacteria in deep Arctic and Antarctic ice cores: a proxy for evolution in oceans over 300 million generations
}

\author{
P. B. Price and R. C. Bay \\ Physics Department, University of California, Berkeley, CA 94720, USA \\ Correspondence to: P. B. Price (bprice@ berkeley.edu) \\ Received: 30 April 2012 - Published in Biogeosciences Discuss.: 6 June 2012 \\ Revised: 10 August 2012 - Accepted: 29 August 2012 - Published: 5 October 2012
}

\begin{abstract}
Using fluorescence spectrometry to map autofluorescence of chlorophyll (Chl) and tryptophan (Trp) versus depth in polar ice cores in the US National Ice Core Laboratory, we found that the Chl and Trp concentrations often showed an annual modulation of up to $25 \%$, with peaks at depths corresponding to local summers. Using epifluorescence microscopy (EFM) and flow cytometry (FCM) triggered on red fluorescence at $670 \mathrm{~nm}$ to study microbes from unstained melts of the polar ice, we inferred that picocyanobacteria may have been responsible for the red fluorescence in the cores. Micron-size bacteria in all ice melts from Arctic and Antarctic sites showed FCM patterns of scattering and of red vs. orange fluorescence (interpreted as due to Chl vs. phycoerythrin (PE)) that bore similarities to patterns of cultures of unstained picocyanobacteria Prochlorococcus and Synechococcus. Concentrations in ice from all sites were low, but measurable at $\sim 1$ to $\sim 10^{3}$ cells cm$~^{-3}$. Calibrations showed that FCM patterns of mineral grains and volcanic ash could be distinguished from microbes with high efficiency by triggering on scattering instead of by red fluorescence. Average Chl and PE autofluorescence intensities showed no decrease per cell with time during up to $150000 \mathrm{yr}$ of storage in glacial ice. Taking into account the annual modulation of $\sim 25 \%$ and seasonal changes of ocean temperatures and winds, we suggest that picocyanobacteria are windtransported year-round from warmer ocean waters onto polar ice. Ice cores offer the opportunity to study evolution of marine microbes over $\sim 300$ million generations by analysing their genomes vs. depth in glacial ice over the last $700000 \mathrm{yr}$ as frozen proxies for changes in their genomes in oceans.
\end{abstract}

\section{Introduction}

Although glacial ice is the purest naturally occurring solid on Earth, it is not completely devoid of impurities. Increasing accumulation of snow in the polar regions leads first to firn ice that is permeable to atmospheric gases and then to fully dense $\left(0.915 \mathrm{~g} \mathrm{~cm}^{-3}\right)$ polycrystalline ice in which ionic impurities and micron-size bacteria reside in liquid veins at junctions where three ice grains meet (Price, 2000). Vein diameter and concentration of soluble impurities in the vein are determined by the free-energy requirement that, in equilibrium, the system of ice plus aqueous solution must be on the freezing line of the compositional phase diagram, which has a eutectic shape with a minimum temperature that is lower than that of the end members water and ionic constituents. For example, when the ice is acidic, with sulfate ions and water as the major constituents, the vein diameter ranges from $\sim 1$ to a few $\mu \mathrm{m}$ at subzero temperatures and increases with depth due to increase in temperature. See Price (2000) for details. In Antarctic and Greenland sites far from coasts, mineral dust, marine salt crystals and other non-microbial impurities in ice contribute $\sim 0.2$ to $1 \mu \mathrm{g} \mathrm{g}^{-1}$ and are usually located at corners where four ice grains meet as well as in the interior of grains. Microbes transported by wind onto ice usually contribute less than $0.1 \mathrm{ng} \mathrm{g}^{-1}$. Bacteria less than several $\mu \mathrm{m}$ in size often reside in veins (Price, 2000), within which they obtain energy and bioelements from ions in the veins but at too low a metabolic rate to permit growth. Eukaryotes such as algae and fungi are also blown onto snow (D'Elia et al., 2009), but almost all are too large to fit into veins. Both large eukaryotes and bacteria trapped in the solid phase of ice may remain alive and metabolise by redox reactions involving diffusion of small molecules such as $\mathrm{CO}_{2}$ and $\mathrm{CH}_{4}$ 
through the ice lattice (Rohde and Price, 2007). For recent reviews of microbial concentrations in ice, see Miteva (2008), Priscu and Christner (2004), Price (2007), and Price (2012).

Our first goal was to use our scanning fluorescence spectrometer in the dark at $-25^{\circ} \mathrm{C}$ to measure chlorophyll $(\mathrm{Chl})$ and tryptophan (Trp) as a function of depth in Greenland and Antarctic ice cores with high statistics. We found that those autofluorescing compounds decrease only about a factor three over a depth of $\sim 2300 \mathrm{~m}$ and that they show an annual modulation of $\sim 25 \%$ between local summer and winter. Our next goal, using differential interference contrast microscopy and epifluorescence microscopy, was to show that the summer-winter modulation of $\mathrm{Chl}$ is due to $\mathrm{Chl}-$ containing cells rather than to organic slime swept up from ocean surfaces. Our next goal was to compare unstained cells from melted ice with cultures of Chl-rich Prochlorococcus (Pro) and Synechococcus (Syn), from which we concluded that those submicron-size cyanobacteria bleached and quickly became invisible while being viewed in epifluorescence microscopy. With flow cytometry, which enables one to study even rapidly bleaching autofluorescing cells, we showed that every sample of melted ice contains cells that emit red fluorescence when excited at $488 \mathrm{~nm}$ and orange fluorescence when excited at $567 \mathrm{~nm}$. Next, comparing stained and unstained cells, we found that $\sim 10 \%$ or more of the micron-size cells in polar ice exhibit the two types of autofluorescence. We then did flow cytometric studies of 12 types of micron-size mineral grains commonly found in glacial ice melts, from which we concluded that their autofluorescence was too weak to interfere with our flow cytometric study of bacterial cells in ice. Finally, we evaluated the importance of wind transport of cells from temperate ocean waters onto polar ice, which led us to conclude that the summer-winter modulation of Pro and Syn concentrations in ice cores is best explained by wind transport from mid-latitudes. For a typical generation time of 1 day for Pro, Syn, and other common bacteria in warm oceans, ice cores offer the opportunity to study evolution over $\sim 300$ million generations by analysing the genomes vs. depth of those blown onto the oldest glacial ice and preserved without mutations at subzero temperature.

\section{Materials and methods}

The Berkeley Fluorescence Spectrometer uses a downwardpointing Photon Systems 224-nm HeAg laser (> $5 \mathrm{~mW}$ peak power) to excite fluorescence in an ice core with a smoothly planed surface cut parallel to the long axis. The laser, focused into a $\sim 3 \mathrm{~mm}$ circular beam, provides $1 \mu \mathrm{J}$ per pulse at a rate of $12 \mathrm{~Hz}$. Autofluorescence directed upward out of the ice is detected with 7 photon counters surrounding the laser and covered by narrow-bandpass filters at 300, 320, 340, 360, 380,670 and $710 \mathrm{~nm}$. The first five channels are used to distinguish tryptophan (Trp) from other fluorescent grains in the ice. Trp has a broad emission peak at 320 to $340 \mathrm{~nm}$ that char-
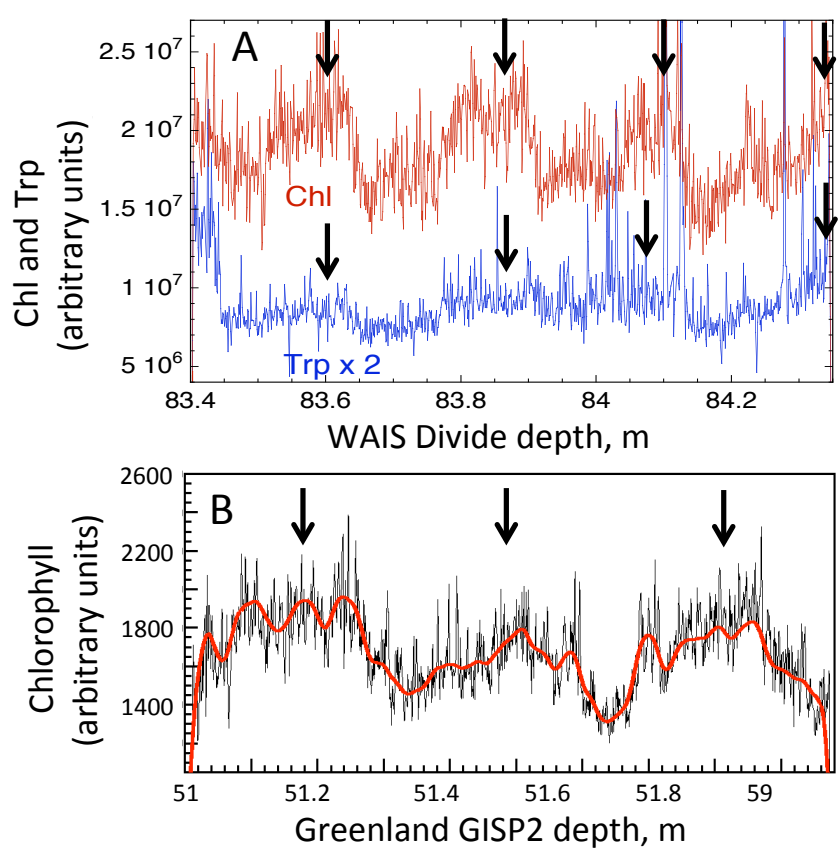

Fig. 1. Chl autofluorescence (arbitrary units) at several depths in ice cores showing fluctuations consistent with summer-winter variations. (A) Chl and Trp over $4 \mathrm{yr}$ in WAIS Divide ice; summer maxima are marked with arrows; (B) $\mathrm{Chl}$ in Greenland ice shows maxima during 3 summers; wiggly red line is a spline fit to the data.

acterises protein fluorescence in cells. A signal in the $670 \mathrm{~nm}$ channel, with low counts at 380 and $710 \mathrm{~nm}$, detects both chlorophyll (Chl) and pheophytin, a product of the decomposition of Chl (French et al., 1956). A strong signal in the $710 \mathrm{~nm}$ channel is used to detect fluorescence from a thin layer of mineral grains transported from a volcanic eruption. With a $1-\mathrm{m}$ ice core moving horizontally at $1 \mathrm{~m}$ per minute, the BFS acquires 1300 seven-channel spectra per meter. It requires a setup time of $2 \mathrm{~min}$ to change from one core to another and align it. Two persons can scan $\sim 80 \mathrm{~m}$ of ice per 6-h day. Trp is difficult to separate cleanly from residues of the organic fluid used to drill deep boreholes, mainly because of fluid-filled nanocracks that may penetrate up to $1 \mathrm{~cm}$ or more during drilling. Cores that are drilled dry are less likely to be contaminated, but are available only down to a depth of $\sim 250 \mathrm{~m}$. Chl is far less likely to suffer from organic contamination than Trp. Figure 2a shows Trp amplitudes oscillating in phase with $\mathrm{Chl}$ in dry-drilled ice at a depth of 83-84 m. Figure $2 b$ shows $\mathrm{Chl}$ in Greenland ice for three years; the wiggly red line is a spline fit.

Portions of ice cores were sealed in plastic bags and stored in freezers at $-30^{\circ} \mathrm{C}$. Working in a laminar flow bench frequently scrubbed with $70 \%$ ethanol, we tried various procedures for removing ice pieces from a core and cleaning their surfaces. Initially we tried melting ice in concentrations of $\mathrm{NaCl}$ up to $3.5 \%$ in order to reduce the osmotic shock to cells that had lived in seawater and been blown directly onto 
dry, frozen water ice that we later allowed to melt. This procedure yielded concentrations of cells that were sometimes higher by a factor up to 2 than those allowed to melt without salt. We eventually eliminated the salt-wash step as not advantageous enough to be worth the risk of sample contamination. To prepare samples of firn ice (surface down to 70 to $150 \mathrm{~m}$ depending on the site) we broke off $50-$ to $200-\mathrm{g}$ pieces with a sterilised chisel, shaved off 1 to $2 \mathrm{~mm}$ from the surfaces with a repeatedly sterilised knife, melted surface regions of the pieces in distilled water that we had passed through a $0.1 \mu \mathrm{m}$ filter, and then allowed more of the remaining ice to melt in a sterile beaker. This usually left about $50 \%$ of the original ice for study. For ice from depths below the firn we first tried cleaning the ice alternatively in $6 \%$ sodium hypochlorite ("bleach") and distilled, $0.1 \mu \mathrm{m}$-filtered water. This is the technique used by most microbiologists in other laboratories to clean their ice (D'Elia et al., 2009). However, we were still concerned that some of the smallest cells residing in veins along triple junctions of grains in polycrystalline ice (Price, 2000) might be killed by traces of bleach that migrated into the veins. Eventually we settled upon the technique of cleaning ice core samples by thoroughly rinsing their surfaces with $0.1-\mu \mathrm{m}$-filtered distilled water and then allowing some of the remaining ice to melt and be discarded before collecting the final sample in a sterile beaker. We stored the melts in beakers at $4{ }^{\circ} \mathrm{C}$ for 1 to $16 \mathrm{~h}$ in the dark before using flow cytometry. We noticed some deterioration of the quality of FCM plots taken after several days, due to deaths of some of the microbial cells.

We obtained BFS measurements at $0.7 \mathrm{~mm}$ depth intervals along ice cores from GISP2 and D4 (Greenland); from WAIS Divide, Siple Dome, and RIDS (West Antarctica); and from Vostok and South Pole (East Antarctica).

We carried out flow cytometric analyses of samples cut and melted from ice cores at GISP2 and D4 (Greenland); WAIS Divide, Siple Dome, and RIDS (West Antarctica); and South Pole, Dome C, and a USA-Norwegian traverse from South Pole into East Antarctica.

Snow accumulation rates for all sites were taken from values in the literature. The Norwegian-USA traverse from South Pole into East Antarctica during the International Polar Year 2009 gave $3.27 \pm 0.3 \mathrm{~cm} \mathrm{yr}^{-1}$ for site 91 at $76^{\circ} 03^{\prime} 54^{\prime \prime} \mathrm{S}$, $22^{\circ} 27^{\prime} 47^{\prime \prime} \mathrm{E}$ (depth $88 \mathrm{~m}$, age AD 340) from where Dr Joe McConnell collected our ice (Anschütz et al., 2011). McConnell also provided the ice from Greenland site D4, at $71^{\circ} 24^{\prime} \mathrm{N}, 43^{\circ} 54^{\prime} 00 \mathrm{~W}$ (depth $12 \mathrm{~m}$, age AD 1991 and $148 \mathrm{~m}$, age AD 1737). The deposition rate took into account accumulation rate and ice density at the depth of the sample.

Because of the low cell concentration in ice from most sites, we used a Dupont Sorvall RC-5B centrifuge at $14000 \mathrm{rpm}$ for $45 \mathrm{~min}$ at $10^{\circ} \mathrm{C}$ to achieve an order of magnitude increase in concentration that we estimated by comparing cell counts before and after centrifuging. We are aware that centrifuging introduces some mass-dependent bias, for example, by favouring Syn over Pro.
Kathryn Johnson, a student of Lisa Moore (University of Southern Maine), prepared cultures of Pro MED4, MIT9313, SS120, and Syn WH8102 (described in Moore et al., 1995). Kate Mackey (Stanford University) provided Syn cultures from five marine locations (to be published). Alex Worden (MBARI) provided cultures of Ostreococcus OT495 P67 and OT495 P118 (Worden et al., 2004). We stored a few vials of cultures at $4{ }^{\circ} \mathrm{C}$ for quick access and froze the remainder at $-30^{\circ} \mathrm{C}$ without preservatives for long-term storage. None of the media were found to show autofluorescence.

Dr Steve Ruzin and Dr Denise Schichsnes provided training sessions so that Price and his students could use the Biological Imaging Facility of the College of Natural Resources at Berkeley to count cell concentrations and measure sizes of both stained and unstained cells in ice as a function of depth. Differential Interference Contrast Microscopy (DIC), bright-field microscopy, epifluorescence microscopy (EFM) and filter cubes for a variety of wavelengths such as DAPI and FITC were used. A Chl filter cube with excitation filter at $480 / 30 \mathrm{~nm}$, dichroic long-pass filter at $505 \mathrm{~nm}$ and emission filter at $660 / 50 \mathrm{~nm}$ was used to measure $\mathrm{Chl}$. The other filter cubes were long-pass; for example, FITC had 470/40 excitation and $515 \mathrm{~nm}$ long-pass. They were used in the initial stages of the EFM scans of unstained cells to characterise the distribution of types of autofluorescence in noncyanobacteria. For the EFM images in Fig. $3 c$ we used a Hamamatsu C8484 black and white 12-bit CCD camera.

Dr Ruzin provided "Insti-Fluor L/D" slides (patent pending) that contain a freshly prepared live/dead stain. They are the dry and stable version of the "Live/Dead" fluorescent solution of SYTO-BC and propidium iodide used to distinguish live cells by their green fluorescence and dead cells by their red fluorescence when viewed with a FITC filter. The digital colour camera was a Q-imaging Micropublisher 5.0 RTC. The procedure was to place a $10 \mu \mathrm{l}$ aliquot of cells into a shallow well in a microscope slide containing the dry stain and seal it with a cover slip.

Hector Nolla, manager and senior operator of the Berkeley Flow Cytometry Facility (http://biology.berkeley.edu/crl/ flowcytometry.shtml), ran the Cytopeia Influx Sorter. For each run the Influx was rigorously cleaned: the tubing for the sheath fluid was repeatedly rinsed with $3 \%$ bleach and then 0.2- $\mu \mathrm{m}$-filtered distilled water until a Chl vs. PE plot and a Chl vs. side scatter (SSC) or forward scatter (FSC) plot of the water were clean except for electronic noise. The sheath fluid was $0.2-\mu \mathrm{m}$-filtered 1 X PBS (phosphate-buffered saline). The flow rate was kept at 25 psi. Because of the low concentration of cells and debris in melted ice, the $0.2 \mu \mathrm{m}$ filter did not need to be replaced or the fluidics cleaned more than once in a 5-h run. The voltages for the Influx photomultiplier tubes (PMT) were usually set at $219 \mathrm{~V}$ for FSC, $367 \mathrm{~V}$ for SSC, $544 \mathrm{~V}$ for $670 \mathrm{~nm}$ and $565.5 \mathrm{~V}$ for $593 \mathrm{~nm}$. During each session on the Influx we included Fluoresbrite-YG 0.3-, $0.5-$, and 1- $\mu \mathrm{m}$ calibrated beads (Polysciences, Inc.). Using a $488 \mathrm{~nm}$ argon laser (Coherent, San Jose, CA) for excitation, 
we recorded Chl fluorescence from each cell at $670 / 20 \mathrm{~nm}$ and $200 \mathrm{~mW}$ power. We used the same laser for side scattered light (SSC) and forward scattered light (FSC). Using the $567 \mathrm{~nm}$ laser, we excited PE fluorescence at $593 / 40 \mathrm{~nm}$ emission (orange) with PMT gain set high enough to map its fluorescence even at low intensities. We also measured autofluorescence of nicotinamide adenine dinucleotide (NADH) at $460 / 50 \mathrm{~nm}$ (excited by the $366 \mathrm{~nm}$ UV laser) as a function of FADH (flavin adenine dinucleotide) at $530 / 40 \mathrm{~nm}$ (excited by the $488 \mathrm{~nm}$ laser) for a future study. Plots of FADH autofluorescence at $540 \mathrm{~nm}$ vs. NADH autofluorescence at $460 \mathrm{~nm}$ provide information on the oxidation state and metabolism of both bacteria and eukaryotes (Chance et al., 1962).

The calculation of cell concentration in an ice sample took into account both the volume of melted ice collected in the flow cytometer during an FCM run and the increased concentration due to centrifuging. In order to obtain at least $10^{2}$ cells $\mathrm{ml}^{-1}$ per FCM run, for ice with very low cell concentrations we filled a $4 \mathrm{ml} \mathrm{FCM} \mathrm{vial} \mathrm{with} \mathrm{melted} \mathrm{ice} \mathrm{that}$ had been centrifuged twice to increase the cell concentration by a factor up to 25 .

We analysed the flow-cytometric data using FlowJo software (TreeStar Inc.). In order to study only cells that contained $\mathrm{Chl}$ and to reject mineral dust, we triggered on values of Chl consistent with the minimum values of Chl in MED4 cultures. To estimate the concentration of mineral dust, we tried triggering on side scattering instead of Chl. This convinced us that dust particles were present, but could be rejected by triggering on an optimal value of Chl. In analysing for Pro and Syn, our standard procedure was to gate on values of SSC that excluded noise and yet were sensitive to cells somewhat smaller than Pro and Syn judging from locations along a SSC axis of $0.3 \mu \mathrm{m}$ beads that were run during the same session as were the melted ice samples. The two PE channels 11 and 12 out of the 4096 channels on the PE scale in Chl vs. PE plots always had one- to two-orders of magnitude more counts per bin than in all other PE channels. Those subpopulations may have been due to Pro cells with very low PE concentrations and sizes consistent with submicron cells that passed the SSC gate.

\section{Results}

\subsection{Chl autofluorescence emitted from unmelted glacial ice}

The Berkeley group has developed several generations of scanning spectrometers that map autofluorescence of microbes in ice (Bramall, 2007; Rohde, 2009). With the most recent version - the Berkeley Fluorescence Spectrometer (BFS) - we obtained spectra of protein-bound tryptophan (Trp) and chlorophyll (Chl) at $0.7 \mathrm{~mm}$ intervals along thousands of meters of ice core at NICL. The BFS distinguishes the autofluorescence of Trp in cells from free Trp by virtue of the fact that, when excited at $224 \mathrm{~nm}$, free Trp has a peak at $\sim 350 \mathrm{~nm}$, whereas Trp bound in cells has an emission peak shifted shortward by up to $\sim 40 \mathrm{~nm}$ (Bramall, 2007). Figure 1 shows 1-m averages of $\mathrm{Chl}$ vs. depth in ice cores from 2 sites in Greenland (GISP2 and site D4), 3 sites in West Antarctica (WAIS Divide, the Ross Ice Drainage System (RIDS) and Siple Dome), and 2 sites in East Antarctica (Vostok and South Pole) at depths from $120 \mathrm{~m}$ to $2300 \mathrm{~m}$. We did not obtain ice from enough depths at Dome $\mathrm{C}$ or the US-Norwegian traverse to provide useful statistics on depth-dependence. The average $\mathrm{Chl}$ intensity was found empirically to decrease as $\sim(\text { depth })^{-0.43}$. To evaluate whether laser pulses might result in photobleaching of Chl-containing cells inside the ice, we shot 50000 pulses of the BFS 224-nm laser into the same spot on an ice core and found no decrease of Chl fluorescence intensity in unmelted ice. This contrasts with our observation (discussed below) that cells of some Chl-containing ecotypes in air undergo photobleaching when studied in an intense microscope beam. Alex Glazer (U. C. Berkeley, personal communication) suggested that phototrophs frozen in ice might de-excite non-radiatively in ice and, thus, might be protected from the photobleaching that they undergo in air. Our FCM measurements discussed below show that the decline in Fig. 1 is not due to gradual loss with time of the Chl autofluorescence per cell of the ice-bound phototrophs that is the main subject of the present work. A possible explanation is that, with increasing age, $\mathrm{Chl}$ that is either not in cells or is in cells with compromised cell walls might decompose into compounds some of which do not fluoresce. Although the physiology is unclear to us, it is possible that micronsize cyanobacteria that adapt to compaction from surface snow into ice without disruption may recover from sunlightinduced bleaching. Cells that end up in a liquid vein must adapt to caustic or acidic conditions in the vein (Price, 2000). We plan to carry out live/dead staining tests on cells as a function of depth to see if the decrease of Chl fluorescence with depth shown in Fig. 1 might be due to gradual death of cyanobacteria due to harsh conditions in the ice.

\subsection{Summer-winter modulation of Chl autofluorescence in glacial ice}

Figure 2 gives examples of periodic oscillations with depth (and, therefore, time) of the autofluorescence intensity of Chl and Trp that we discovered in the two cores with accumulation rates high enough for us to acquire good statistics and resolution. They are (a) WAIS Divide in W. Antarctica with $24 \mathrm{~cm} \mathrm{yr}^{-1}$ ice equivalent and (b) GISP2 at Summit, Greenland, with $\sim 22 \mathrm{~cm} \mathrm{yr}^{-1}$ ice equivalent. In Fig. $2 \mathrm{a}$, the weaker oscillations of tryptophan (Trp) are seen to match in phase those of Chl. The arrows point to peaks at depths corresponding to summer periods. We determined the phase of the Chl oscillations in the WAIS Divide ice core by comparing our peaks with the summer-winter oscillations of the annual layers found in a parallel portion of the same WAIS Divide ice 

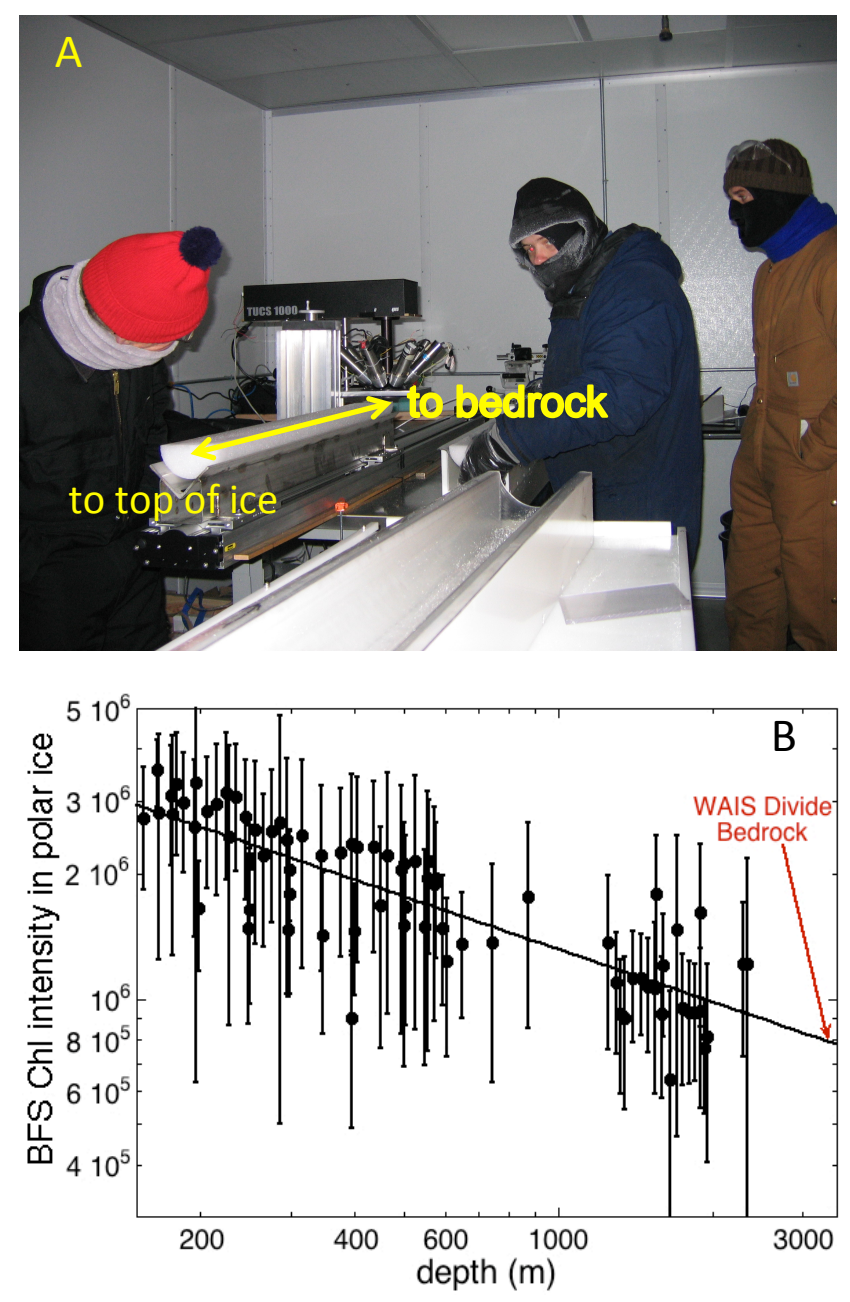

Fig. 2. (A) The Berkeley Fluorescence Spectrometer (BFS) maps fluorescence of $\operatorname{Trp}$ and $\mathrm{Chl}$ with 1400 spectra $^{-1}$ in 2 min. Ice protects phototrophic cells from photobleaching. (B) Intensity of Chl autofluorescence in ice cores from 7 polar ice locations: 2 sites in Greenland (GISP2 and site D4), 3 sites in West Antarctica (WAIS Divide, Ross Ice Drainage System (RIDS) and Siple Dome), and 2 sites in East Antarctica (Vostok and South Pole). Depths extend from $120 \mathrm{~m}$ to $2300 \mathrm{~m}$; each point is an average over $\sim 10^{3}$ depths per metre and over the 7 locations.

core (Cole-Dai et al., 2006). Chl in ocean surface waters has been mapped continuously over several years by SeaWiFS satellite ocean colour data (Gregg, 2008). They found that oceanic Chl maxima occur in the northern summer (July) for latitudes in the North Atlantic Ocean and in the southern summer (January) for latitudes between $-40^{\circ} \mathrm{S}$ and Antarctica. Our Chl intensity as a function of time in WAIS Divide ice agrees in phase with maxima of the Southern Ocean Chl data. As Fig. $2 b$ shows, we also found annual Chl maxima in the GISP ice, presumably with maxima in Arctic summer. The wiggly curve in Fig. $2 \mathrm{~b}$ is a spline fit. For both the WAIS
Divide and GISP sites, we know from the age vs. depth relations that the spacing between peaks is $1 \mathrm{yr}$.

\subsection{Differential Interference Contrast (DIC) and Epifluorescence Microscopy (EFM) in melted glacial ice and cultures}

To determine whether the Chl autofluorescence seen by the BFS in the ice came primarily from $\mathrm{Chl}$ in cells, rather than from non-cellular organic slime splashed from ocean surfaces, we first used DIC and EFM to search for microorganisms in melted, unstained ice samples from various locations. The concentration of microbial cells in melts was usually far lower than the concentration of cells in ocean samples. To search for cyanobacteria, we collected particles from melts with volumes $\sim 100 \mathrm{ml}$ onto a $0.2 \mu \mathrm{m} \mathrm{Nu}-$ clepore filter and used a $670-\mathrm{nm}$ Chl, $40 \mathrm{~nm}$ band-pass filter cube to search for Chl-fluorescing cells that showed up red in colour. None were detectable. Although phototrophs such as Chlamydomonas and other algae and fungi with sizes larger than $10 \mu \mathrm{m}$ might, in principle, have contributed to the Chl fluorescence seen with the BFS, we found their concentration to be too small to detect in ice melts. To eliminate large cells and large mineral grains from being detected in either EFM or FCM, we used a $1.2 \mu \mathrm{m}$ syringe filter to remove them from the ice melts before further studies. The strong Chl emission, its annual modulation in the ice cores and the absence of large phototrophs led us to the conjecture that the source of Chl autofluorescence seen with the BFS might in part be due to picocyanobacteria of the genera Prochlorococcus (Pro) and Synechococcus (Syn) or picoeukaryotes such as Ostreococcus (Ostreo), all of which are extremely abundant submicron-size $(\leq 2 \mu \mathrm{m})$ marine microorganisms (Chisholm et al., 1988; Worden et al., 2004). In testing that conjecture, we found that with the Chl filter set we could not detect Pro in melted ice with EFM, even with image intensification. This failure turned out to be due to its extremely rapid bleaching when viewed in its Chl autofluorescence. Using a shipboard flow cytometer, Chisholm et al. (1988) had discovered cells that were smaller and more weakly fluorescent than any observed with microscopy. With these and additional measurements with TEM and HPLC, they concluded that there was a new, extremely small, highly abundant organism (Pro) in the oceans that rapidly bleached during EFM observations. We will discuss our evidence for picocyanobacteria in Sect. 6.

After failing to detect $\mathrm{Chl}$ autofluorescence in Pro and Syn cells from melted ice with EFM, we explored the use of EFM to image cells from ice at other wavelengths. We used a DAPI filter cube to image the autofluorescence of NADH and FAD, which are microbial coenzymes used in microbial respiration to generate ATP. NADH is moderately fluorescent (with a peak at $460 \mathrm{~nm}$ ) in the reduced state when excited at $\sim 340 \mathrm{~nm}$, but does not fluoresce in the oxidized state (Bramall, 2007; Chance et al., 1962), from which it follows 
that cells imaged in NADH autofluorescence provide a lower limit to the true concentration. With a fluorescence spectrometer Nathan Bramall built for his thesis (Bramall, 2007), he used NADH autofluorescence to map cell concentrations as a function of depth in Lake Tahoe. We observed NADH autofluorescence in melted ice samples (data not shown), indicating that microbial cells are in the ice melt. For comparison with the use of NADH and FAD, we initially stained cells in some samples of the same ice with SYBR Green and imaged the yellow-green fluorescence of nucleic acids in the cells with a FITC filter cube. The ratio of concentrations of unstained cells imaged by NADH and FAD autofluorescence to cells stained with SYBR Green was less than 0.5, with large variations. In runs with FCM we detected 5 to 10 times as many cells stained with SYBR Green as in runs with unstained cells. Thus, we attributed the excess of stained fluorescent cells in both the EFM and the FCM to heterotrophic bacteria, which do not contain Chl.

Figure 3a shows an EFM image of stained cells from a depth of $86 \mathrm{~m}$ in WAIS Divide ice. We cleaned the surfaces successively in $5 \%$ sodium hypochlorite (bleach), ethanol and distilled water. We then melted the ice, passed the melt through a $0.2 \mu \mathrm{m}$ Nuclepore filter, stained the cells caught on the filter with SYBR Green, viewed them in EFM with a FITC filter and used a colour digital camera for photomicrography. The cell concentration revealed with staining was $\sim 10^{4} \mathrm{ml}^{-1}$. In stained samples from other depths and other glacial sites, the concentration ranged from $\sim 10 \mathrm{ml}^{-1}$ to $\sim 10^{5} \mathrm{ml}^{-1}$ and was typically up to an order of magnitude higher than that seen without staining.

With EFM and the Chl filter cube, we studied cultures of unstained Pro, Syn and Ostreo. The advantage of studying cells in a culture over trying to study the far lower concentration of cells in melted ice is that one can focus on and photograph some of them in a culture before all of them have disappeared during photobleaching. We found that the $\mathrm{Chl}$ autofluorescence of Pro bleaches within $\sim 1$ s during observation in EFM, that of Syn bleaches within $\sim 20$ s and that of Ostreo is still visible after 10 to $20 \mathrm{~min}$. Pro, Syn and Ostreo are stable against fading when viewed in Differential Interference Contrast microscopy (DIC), which illuminates cells with a far less intense beam than does epifluorescence microscopy. Figure $3 \mathrm{~b}$ shows that in a mixed culture of Pro (small cells) and Syn (larger cells), both Pro and Syn are stable over long times when viewed in DIC. However, during exposure to blue light in EFM, the Pro cells faded too rapidly to be seen (Fig. 3), but were clearly visible in the same fieldof-view in DIC, showing that the photobleaching had not destroyed them. All of the Syn and Ostreo cells were visible in EFM with a Chl filter cube, even after exposure to light for more than 1 min with DIC.

Using Ruzin's live/dead stain, we studied the survival of cells from Pro, Syn and Ostreo cultures that were subjected to sudden freezing at $-30^{\circ} \mathrm{C}$ and then examined after one year. Ninety percent of the Syn cells and $80 \%$ of the Ostreo cells

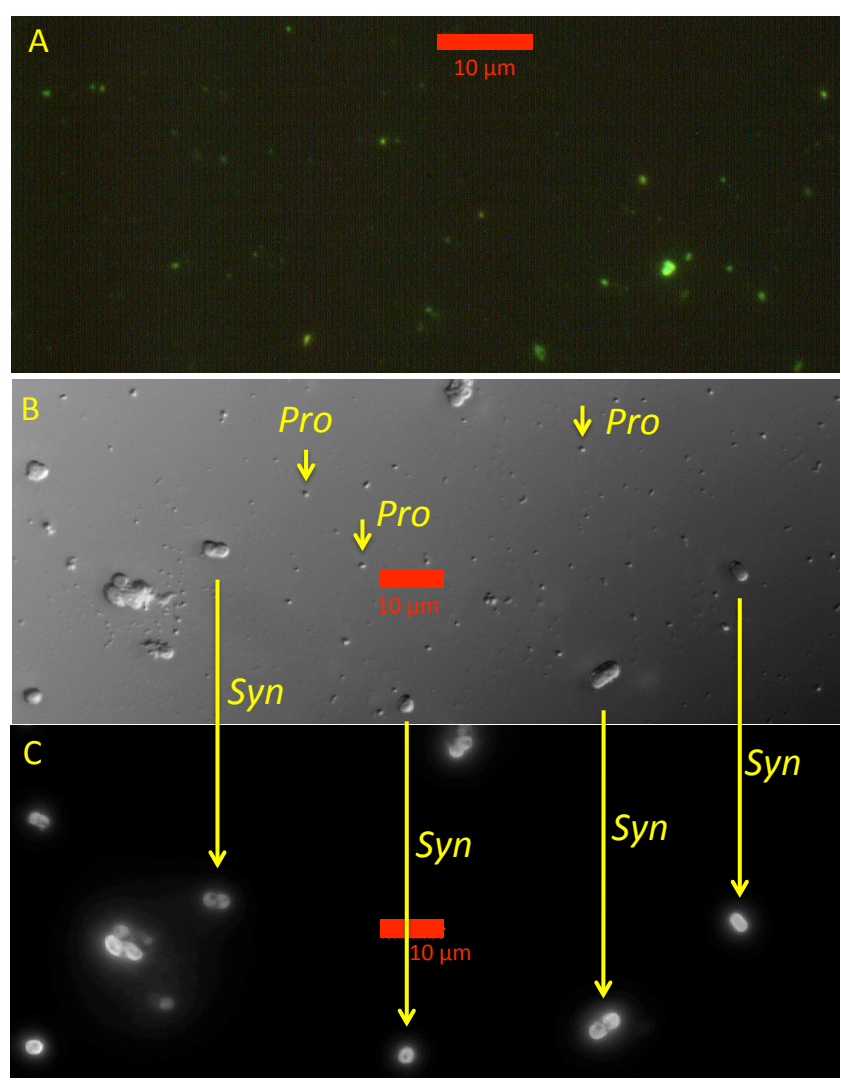

Fig. 3. (A) Epifluorescence microscopy of sub-micron-size cells from a depth of $86 \mathrm{~m}$ in ice from WAIS Divide, stained with SYBR Gold, concentrated onto a $0.2 \mu \mathrm{m}$ Nuclepore filter and viewed with a FITC filter cube. (B) Mixed culture of unstained Pro (tiny cells) and Syn (larger cells) viewed in Differential Interference Contrast (DIC) microscopy; both Pro and Syn are stable. (C) same field-ofview imaged in EFM with a Chl filter cube using a Hamamatsu C8484 black and white 12-bit CCD camera Pro cells bleach within $\sim 1 \mathrm{~s}$ whereas $S y n$ takes $\sim 20 \mathrm{~s}$ to bleach. Scale bars are $10 \mu \mathrm{m}$.

were still alive, whereas only $\sim 45 \%$ of the Pro cells were still alive. Thus, many of them survived freezing at $-30^{\circ} \mathrm{C}$ without having been in contact with liquid water, which suggests that wind-borne cells would survive the shock of deposition onto polar snow. More work needs to be done before we can draw firm conclusions as to the relative resistance of Pro, Syn and Ostreo to abrupt cold shock or to the dependence of survival rate on duration of exposure at $-30^{\circ} \mathrm{C}$ or to residence temperature. We note that Miteva (2008) succeeded in cultivating many taxa of both aerobes and anaerobes that were frozen in the bottom few $\mathrm{m}$ of GISP2 ice, thus, showing that some were still alive after more than $10^{5} \mathrm{yr}$.

\subsection{Flow cytometry of microbial cells from ice melts}

Figure 5a and $\mathrm{b}$ shows flow cytometer plots of chlorophyll (Chl) vs. phycoerythrin (PE) autofluorescence and of Chl vs. side scatter for marine picoplankton made by Marie et 


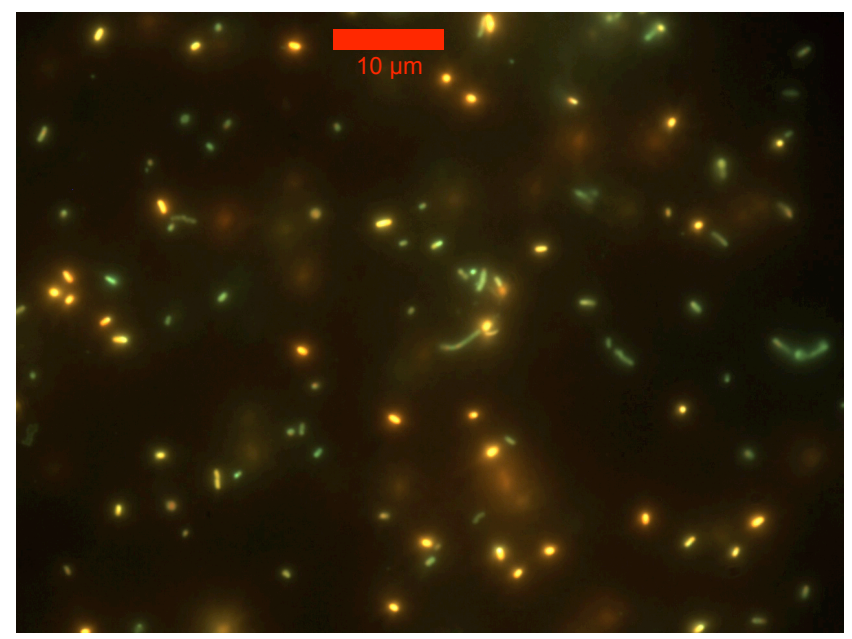

Fig. 4. Cells from a Syn culture kept at $-30^{\circ}$ for $1 \mathrm{yr}$ and then subjected to a live/dead staining procedure. Cells with a yellow-green colour survived with membranes intact; membranes of cells with a red colour lost their integrity and are regarded as dead. Scale bar is $10 \mu \mathrm{m}$.

al. (1999). Their $0.98 \mu \mathrm{m}$ beads ("billes" in French) serve as internal references that relate to sizes of marine picoplankton. Pro cells cluster in a group with weak PE and stronger Chl, Syn cells lie along diagonal lines extending to high PE and high Chl, and picoeukaryotes such as Ostreo have more $\mathrm{Chl}$ than Pro and very low orange fluorescence. Figure 5c and d shows our FCM plots of cultures of Pro, Syn and $O s-$ treo cells, which have similar values of Chl, $\mathrm{PE}$ and side scatter on our Cytopeia Influx flow cytometer to the corresponding marine cells in Fig. 5a and b. MIT9313 is an ecotype of Pro that lives in water deeper than $\sim 80 \mathrm{~m}$ and has evolved with more Chl than MED4 in order to extract energy from the weak sunlight that penetrates to those depths, whereas the low-Chl MED4 Pro ecotype lives at shallower depths (Moore et al., 1995).

In our Influx FCM, five laser beams impinge on individual cells in a downward-directed laminar stream. Each dot in our FCM plots in Figs. 5 to 8 corresponds to a value of intensity of red fluorescence of Chl, of orange fluorescence of PE and of light scattered by a single cell in the forward direction (FSC) or at roughly right angles (SSC) to the laser beam. The number of dots on a Chl vs. PE plot gives the number of cells in a volume of melted ice that passed through the Influx.

We used several methods to enrich our FCM plots in picocyanobacteria and reject heterotrophic bacteria and archaea: (1) to remove most mineral dust and other large particles we passed melted ice through $1.2 \mu \mathrm{m}$ filters. (2) We examined only unstained cells. (3) We triggered at a value of Chl sufficiently high to accept only Chl-containing cells and to reject mineral particles and most background noise. (4) We gated on points with SSC or FSC greater than the value for $0.3-\mu \mathrm{m}$ beads that we ran during the same session. This left us with
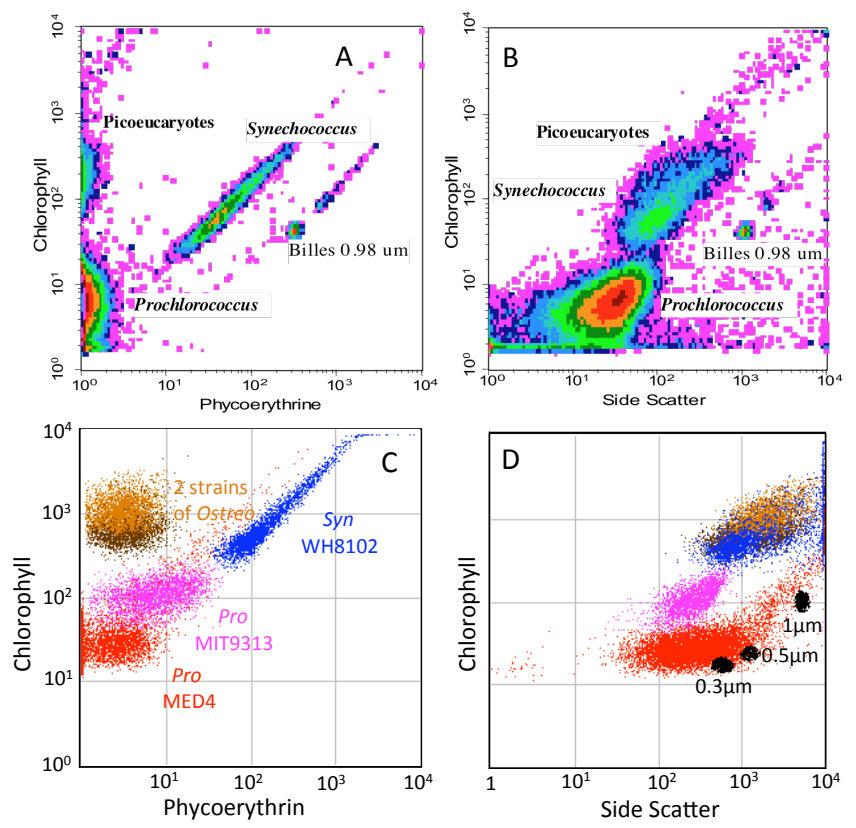

Fig. 5. (A, B) FCM plots of marine picoplankton (Marie et al., 1999); (C, D) this work: cultures of Pro, Syn and Ostreo, with the same colour codes for $\mathbf{D}$ as for $\mathbf{C}$ and with $0.3 \mu \mathrm{m}, 0.5 \mu \mathrm{m}$ and $1 \mu \mathrm{m}$ beads included with the cultures.

Chl vs. PE patterns of cells with size greater than $\sim 0.3 \mu \mathrm{m}$. At the beginning of a day's run, we assessed the background noise level by running the same volume of filtered distilled water that we ran of ice melt. $\sim 50$ to $\sim 300$ counts per $\mathrm{ml}$ of distilled water showed up in the low-scatter region, but no more than 1 or 2 counts per $\mathrm{ml}$ survived the gate on high SSC. Figure 6a, $b$ gives an example of FCM for filtered distilled water, where only two points in a $4 \mathrm{ml}$ sample, labelled in pink, survived the cuts. The green points in Figs. 6 to 8 labelled "low PE" showed up in high concentration in channels with the lowest PE. Many of those low-PE points survived our gate on high-scatter points. We speculate that they may have been picocyanobacteria with very little PE, but significant scatter.

Based on the locations of the beads relative to the points indicated in colours, our plots of Chl vs. SSC or FSC showed that phototrophs in ice have light-scattering properties consistent with sizes ranging from $\sim 0.3 \mu \mathrm{m}$ to more than $\sim 1 \mu \mathrm{m}$. For convenience we used red dots to denote cells in the same region as the Pro cultures as "Pro-like" and blue dots to denote cells in the same region as the Syn cultures as "Syn-like", even though the two sets of dots are not distinctly resolvable from each other.

As can be seen in Figs. 6, 7 and 8, the FCM plots for cells in ice showed strong similarities, regardless of their sites (Greenland or Antarctica) and depths of origin. About a third of the plots had diagonal Chl vs. PE groupings much broader than in the Syn cultures in Fig. 5. Figure 6e provides 
an example. The Syn-like distributions for ice at $12.00 \mathrm{~m}$ and $12.05 \mathrm{~m}$ at site D4 (Fig. 6e-h) were qualitatively different from each other. At $12.00 \mathrm{~m}$ (Fig. 6e) there were two distributions along separate diagonal lines with different slopes. Because of its low Chl concentration and low slope, the one labelled "unknown" is unlikely to be Syn. At a depth of just $5 \mathrm{~cm}$ deeper (Fig. $6 \mathrm{~g}$, h), only one $S y n$-like grouping was present and the cell concentration was much smaller than at $12.00 \mathrm{~m}$. The marked differences in the Pro and Syn patterns at 12.00 and $12.05 \mathrm{~m}$, corresponding to deposition times in the ice differing by $\sim 3$ months, are an indication of the stochastic nature of the sampling and deposition of cells blown from ocean water.

Figure 9 summarises our data on concentrations of Prolike cells, Syn-like cells, cells with both low-PE fluorescence and high scattering, and the ratio of Pro-like to Syn-like cells at various sites for a total of 62 depths. The column with orange points, labelled E. Ant. (East Antarctica), included the South Pole, the US-Norwegian traverse eastward from South Pole and Dome C at 103 and $120 \mathrm{~m}$. Several of the concentrations of Pro-like and Syn-like cells in Dome C ice were lower than $\sim 1$ cell $\mathrm{ml}^{-1}$, consistent with the low snowfall rates, low mineral dust concentrations and low salt concentrations at Dome C. To achieve sensitivity to a cell concentration as low as 1 cell $\mathrm{ml}^{-1}$, we used two successive steps of centrifuging of melt and did FCM on 2 to $4 \mathrm{ml}$ of the concentrated melt (see Materials and Methods). Median Pro-like concentrations (black lines in Fig. 9a) were $85 \mathrm{ml}^{-1}$ for GISP (Greenland), $25 \mathrm{ml}^{-1}$ for WAIS Divide (West Antarctica) and $\sim 1 \mathrm{ml}^{-1}$ for East Antarctica. The median Pro-like / Synlike ratio ranged from $\sim 1$ to $\sim 3$ from one site to another, but with large uncertainty in view of the absence of a gap between the two populations and higher efficiency for concentrating Syn-like than Pro-like cells by centrifugation. The overall median values for all sites were 24 Pro-like cells ml ${ }^{-1}$ and 11 Syn-like cells $\mathrm{ml}^{-1}$. From these data we estimate that median DNA concentrations were only $\sim 50 \mathrm{pg}^{-1}$ for Prolike cells and $\sim 70 \mathrm{pg} \mathrm{l}^{-1}$ for $S y n$-like cells. The genomes of the picocyanobacteria are quite small: 1.66 and $1.75 \mathrm{Mb}$ for Pro MED4 and MIT9313 (Rocap et al., 2003), 2.41 Mb for Pro SS120 (Dufresne et al., 2003), and 2.43 Mb for the Syn WH8102 strain (Palenik et al., 2003).

We found no evidence for Ostreo in any of our unstained ice melts.

\subsection{Flow cytometry of weakly fluorescent mineral grains}

Until now, no one had reported use of flow cytometry to attempt to detect inorganic grains in either oceans or ice. Current techniques used for rapid on-line measurements of dust grains in ice include Coulter counters and laser microparticle detectors. It is well known that mineral grains are transported by winds to Greenland ice from the Taklimakan desert in China (Ruth et al., 2003) and from desert regions of Patagonia and Australia to Antarctic ice (Li et al., 2008; Lambert et al., 2008). Small volcanic ash particles are occasionally found in discrete layers in Antarctic ice (Kurbatov et al., 2006; Basile et al., 2001). Using a laser-powered downhole optical logging tool, Bramall et al. (2005) measured concentrations of both mineral dust and volcanic ash with $\mathrm{mm}$ depth resolution in many boreholes in both Antarctica and Greenland. From $\sim 20$ to $\sim 100$ times as many dust grains are deposited in polar ice during glacial maxima as in glacial minima. During the Holocene (the present warm period) the average dust concentration has been 40 to $50 \mathrm{ng} \mathrm{g}^{-1}$ in Greenland ice and $\sim 10 \mathrm{ng} \mathrm{g}^{-1}$ in Antarctic ice (Price et al., 2009). In a detailed study of dust in the NGRIP Greenland core with a laser microparticle detector, Ruth et al. (2003) measured log normal modes of $1.3 \mu \mathrm{m}$ during the Holocene and $1.7 \mu \mathrm{m}$ during the LGM. The smallest of these mineral dust grains would have passed through our $1.2 \mu \mathrm{m}$ filter. With a similar technique, Koffman et al. (2012) measured dust concentrations in 31 particle size channels down to a depth of $577 \mathrm{~m}$ in a WAIS Divide ice core. She typically found 200 to $10^{3} \mathrm{ml}^{-1}$ with size less than $1.2 \mu \mathrm{m}$.

To evaluate whether our flow cytometer would detect micron-size unstained mineral grains with a signature that could distinguish them from unstained microbial cells, we obtained coarse grains from 12 types of minerals from Gustaf Arrhenius. They included the dominant mineral grains in ice cores: clay minerals (illite, montmorillonite, kaolinite and smectite), feldspar, quartz and other minerals less commonly found in ice cores. From Chris McKay we obtained volcanic ash grains from a Pico di Orizaba (Mexico) eruption, particles with a composition similar to Martian soil and soil from the Dry Valleys in Antarctica. We baked the grains at $350{ }^{\circ} \mathrm{C}$ to destroy bacteria, then ground them in a mortar and pestle in order to reduce their size sufficiently to pass them through a $1.2 \mu \mathrm{m}$ filter.

Bramall (2007) had found that autofluorescence of unstained mineral grains was typically far weaker than of phototrophs at wavelengths used in our FCM. If we triggered on $670 \mathrm{~nm}$ fluorescence at the same level we used to analyse phototrophs ( $\sim 6$ to 10 units as shown in Figs. 6-8), the count rate for mineral grains was almost zero. By contrast, if we triggered on SSC, the count rate from the mineral grains was $>10^{3}$ times higher and clearly visible in side scatter. Figure $8 \mathrm{k}$ and 1 shows the results of running kaolinite grains for 50000 counts (shown in red) with a trigger set at $10^{2}$ units of SSC. Only a few counts showed up above the noise level. The great advantage of using the Chl trigger rather than the SSC or FSC trigger is that it rejects counts due to dust particles.

Table 1 compares ratios of concentrations in Antarctic ice relative to Greenland ice for Trp-containing microbes, Chl-containing microbes, mineral dust and ash, and nonmicrobial aerosols. Price et al. (2009) used the BFS to identify $\operatorname{Trp}$ as a proxy for all microbes in ice cores at NICL based on analysis of its emission in five channels at 300, 320, 340,360 and $380 \mathrm{~nm}$. In the present work we used that same 


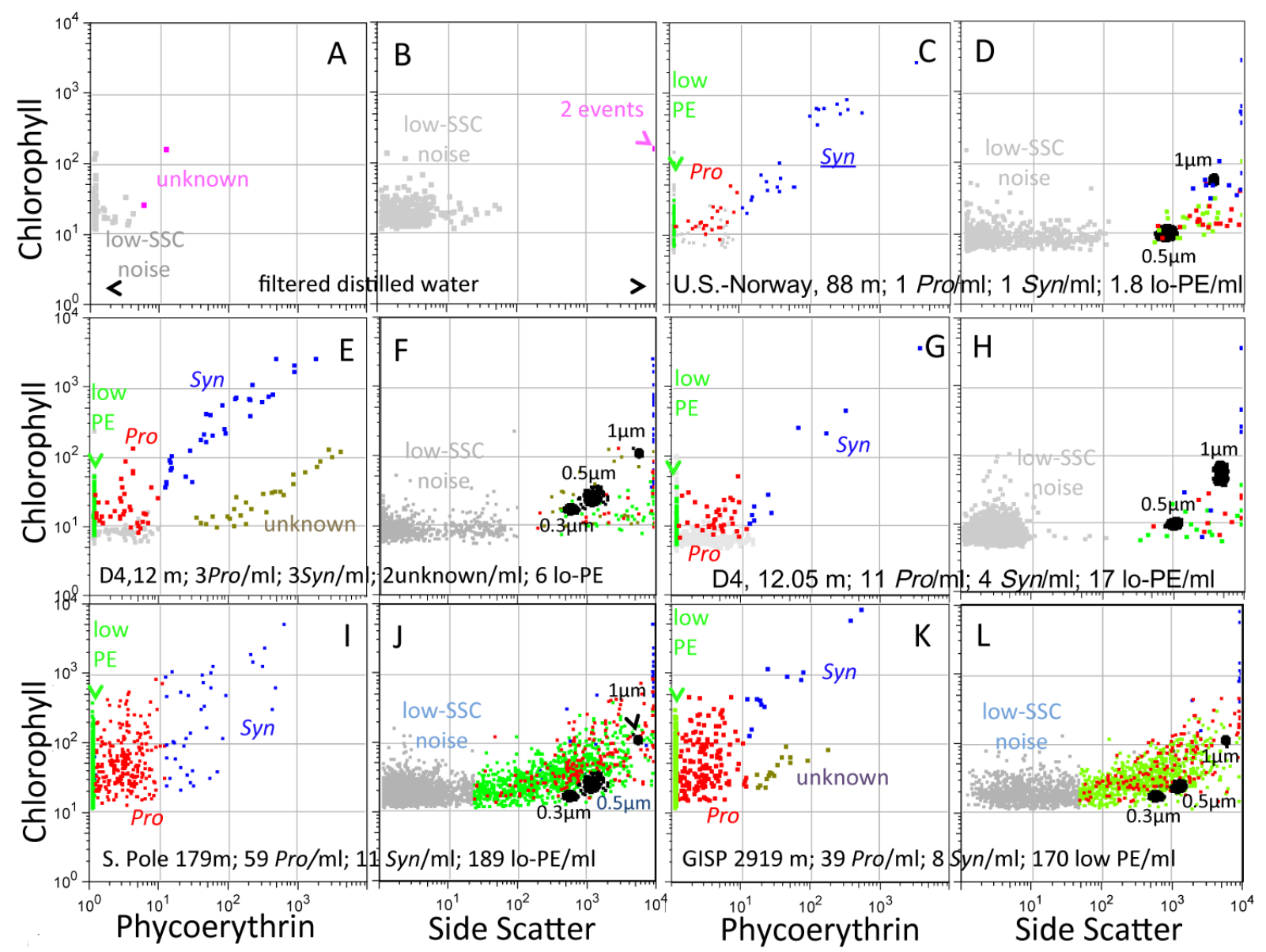

Fig. 6. FCM plots: (A, B) Distilled water was passed through a $0.2 \mu \mathrm{m}$ filter, thresholded on Chl as in the other FCM plots and gated on high SSC; in this and the other plots, gated-out noise is in gray, cells with very low PE are shown in green and the cells were not stained. (C, D) Pro-like and Syn-like cells from an ice core from a depth $88 \mathrm{~m}$ collected during a traverse from South Pole into East Antarctica (Anschütz et al., 2011). (E, F) Pro-like and Syn-like cells and cells of an unknown taxon from $12.00 \mathrm{~m}$ depth at site D4, $10 \mathrm{~km}$ west of the Greenland site at Summit. (G, H) Pro-like and Syn-like cells at $12.05 \mathrm{~m}$ at site D4. (I, J) Pro-like and Syn-like cells from $179 \mathrm{~m}$ at South Pole. (K, L) Pro-like and Syn-like cells, and cells of an unknown taxon from $2919 \mathrm{~m}$ depth at GISP2 (Summit). Beads in D, F, H, J and $\mathbf{L}$ were added after the runs, with all FCM settings unchanged. The gain on the Chl phototube was set higher for plots $\mathbf{I}$ to $\mathbf{L}$ than for $\mathbf{A}$ to $\mathbf{H}$. Cell concentrations were calculated after dividing by volume of liquid run and concentration resulting from centrifugation.

instrument to map $\mathrm{Chl}$ in ice cores by analysing the two channels at 670 and $710 \mathrm{~nm}$. Price et al. (2009) determined the concentrations of non-microbial aerosols from the deviations of their fluorescence spectra from the spectrum of Trp, which has a peak at $\sim 320 \mathrm{~nm}$ when bound in cells. In Table 1 we note that Antarctic ice has a lower concentration of all small particles by a factor of several than Greenland ice.

Table 2 gives the concentrations of all Trp-containing cells, of Chl-containing cells and of dust in several ice cores from Greenland and Antarctica. Taking into account the large rejection factor for discriminating against mineral grains in FCM with the Chl trigger, we conclude that the ratio of dust concentration to cell concentration is not large enough to be a source of background in our study.

\section{Discussion}

\subsection{Dwarf cells in GISP ice}

Dwarf cells in GISP ice. Miteva and Brenchley (2005) have found ultrasmall microorganisms in silty ice within $2 \mathrm{~m}$ of the clay substrate of the Greenland GISP ice. They used filtration, SEM, EFM, FCM and comparative genomic fingerprinting to study sizes, morphology, culturability and genomes of bacteria in the silty ice. They defined ultrasmall as having a volume $<0.1 \mu \mathrm{m}^{3}$. They recorded numerous cases of bacteria with size as small as $0.2 \mu \mathrm{m}$. Some of their smallest cells were able, by deforming, to pass through Nuclepore filters with $0.1 \mu \mathrm{m}$ hole size. They stained the cells with SYTO13 or a live/dead stain and characterised them in FCM with side scatter vs. green fluorescence. Their failure to 


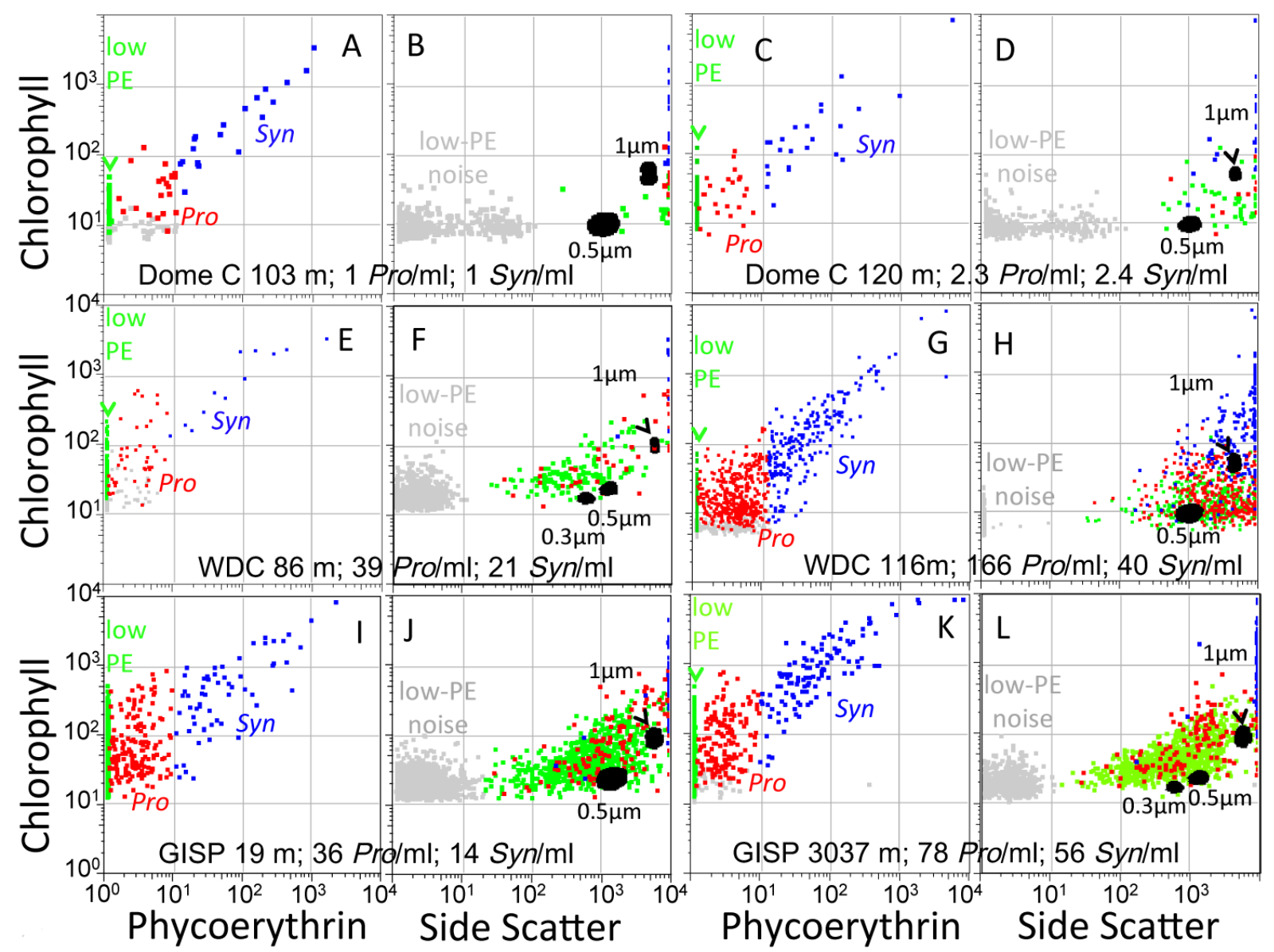

Fig. 7. Pairs of FCM plots of unstained cells, labelled with sites of ice cores, depths and concentrations of Pro-like and Syn-like cells. Dots are colour-coded for Pro-like cells (red), cells with very low PE (green) and Syn-like cells (blue). The gain on the Chl phototube was set higher for plots $\mathbf{E}, \mathbf{F}$, and $\mathbf{I}$ to $\mathbf{L}$.

Table 1. Concentrations of picocyanobacteria, dust, microbial cells and non-cellular aerosols in Antarctic relative to Greenland ice

\begin{tabular}{lll}
\hline Particles & Location & Concentration ratio \\
\hline picocyanobacteria & Antarctic/Greenland ice & $0.35 \pm 0.11$ \\
mineral dust $^{1}$ & Antarctic/Greenland ice & $0.42 \pm 0.16$ \\
all Trp-containing microbes $^{2}$ & (WAIS ice)/(GISP2) ice & $0.19 \pm 0.1$ cell cell $^{-1}$ \\
aerosols with no Trp & (WAIS ice)/(GISP2) ice & $0.24 \pm 0.12$ particle particle $^{-1}$ \\
\hline${ }^{1}$ This work. & &
\end{tabular}

detect picocyanobacteria is not inconsistent with the present work because most of their ice samples were from the silty basal ice that predated the onset of glaciation in Greenland and because they always stained their cells rather than relied on autofluorescence of cells in EFM or FCM.

\subsection{Transport of picocyanobacteria from temperate oceans to glacial ice}

Although indigenous Syn cells are found in summer at very high-latitude sites such as Antarctic coastal sites (Walker and Marchant, 1989), Arctic and Antarctic lakes (Vincent et al., 2000) and Ace Lake, Antarctica (Powell et al., 2005), Pro cells have not been identified at high latitude (Vincent, 2000a). The total populations of Syn cells and larger cyanobacteria (Vincent, 2000b) found in the occasional isolated high-latitude sites such as lakes and cryoconite holes (Christner et al., 2003) are far smaller than could account for the Syn-like cells we found at all depths and in all Arctic and Antarctic ice cores. The ratio of Pro / Syn cells at local ocean and lake temperature is zero instead of $\sim 3$, and the area of the lake sources + ocean sources at $0^{\circ} \mathrm{C}$ is far smaller than the area of Antarctica over which we found the cells we attributed to picocyanobacteria. We, therefore, rejected an explanation of sources of the Pro-like and Syn-like cells that would have required evolution of strains of Pro and Syn into psychrophiles or psychrotrophs that have been living in waters close to the coasts of Antarctica and Greenland for at least $150000 \mathrm{yr}$.

Assuming that some of the cells we labelled with red dots (for Pro-like) and blue dots (for Syn-like) are indeed 

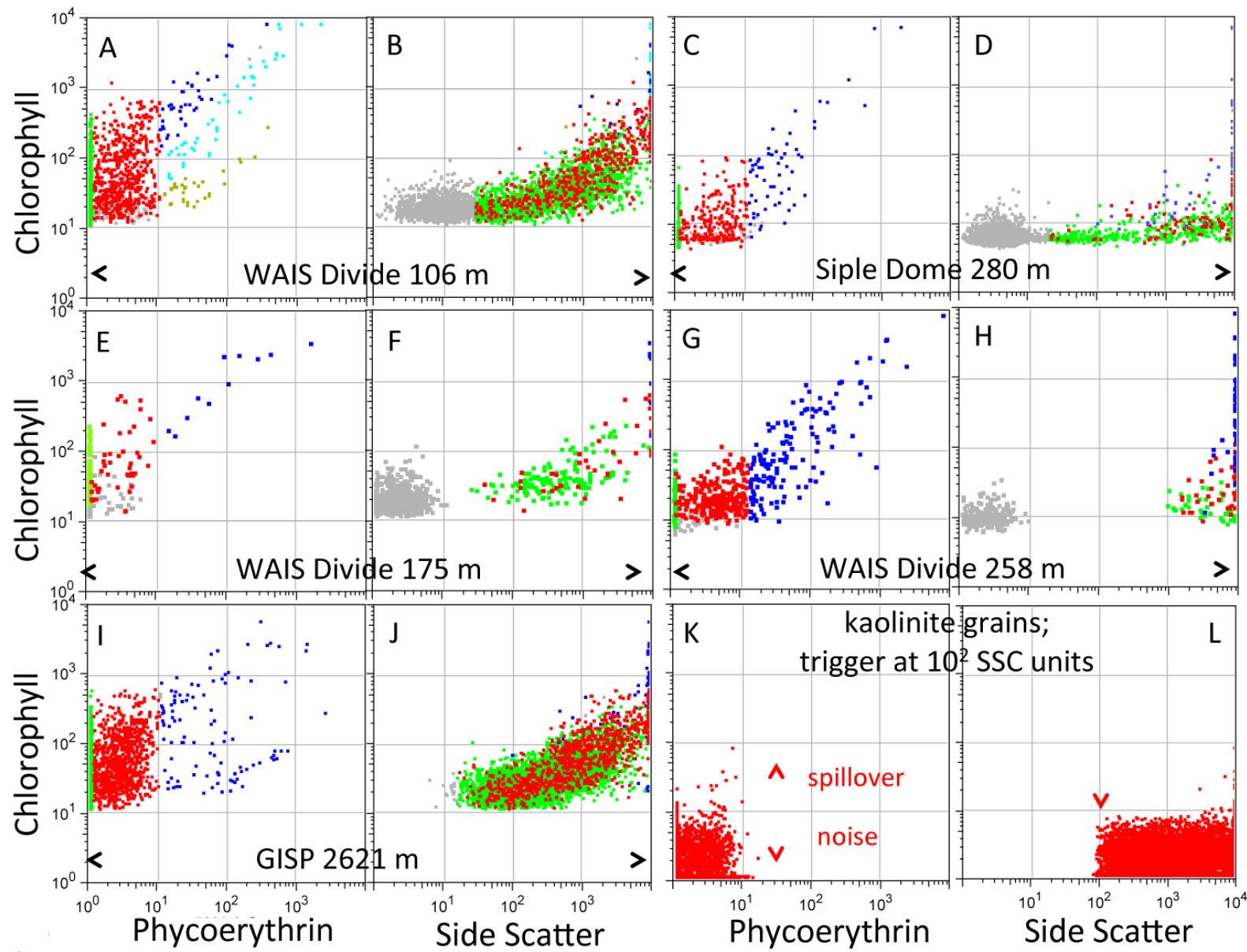

Fig. 8. (A) to (J) show FCM plots of unstained cells from ice cores. Points in gray at low SSC were gated out before plotting Chl vs. PE. The gain on the Chl phototube was set higher for plots (A, B, E, F, I and J). Plots of kaolinite grains with trigger on 100 units of SSC are shown in $(\mathbf{K})$ and (L). See text for discussion.

Table 2. Concentrations of various particles in Antarctic and Greenland ice at depths $<400 \mathrm{~m}$

\begin{tabular}{|c|c|c|c|c|}
\hline Particles & Location & Particles $\mathrm{ml}^{-1}$ & Ratios & Reference \\
\hline All cells (Trp) & GISP & $(0.1-1.5) \times 10^{4}$ & & Price et al. (2009) \\
\hline “ & WAIS & $(0.08-1.3) \times 10^{4}$ & & Price et al. (2009) \\
\hline “ & Siple Dome & $(0.15-0.7) \times 10^{4}$ & & Price et al. (2009) \\
\hline Chl-rich cells & GISP & 480 & & this work \\
\hline Chl-rich cells & WAIS & 170 & & this work \\
\hline Dust (all sizes) & NGRIP & $\sim 10^{4}$ & & Ruth et al. (2003) \\
\hline Dust (all sizes) & Dome C & $\sim 2500$ & & Lambert et al. (2011) \\
\hline Dust ( 0 to $1.2 \mu \mathrm{m})$ & WAIS & $\sim 200$ to $\sim 10^{3}$ & & Koffman et al. (2012) \\
\hline All cells/dust & Greenland & & $>0.05^{*}$ & Price et al. (2009) \\
\hline Chl-rich cells/dust & Greenland & & $\sim 1^{*}$ & this work \\
\hline Chl-rich cells/dust & WAIS & & $\sim 0.1$ to $10^{*}$ & this work; Koffman et al. (2012) \\
\hline
\end{tabular}

${ }^{*}$ Ratio is quite uncertain due to uncertainty in fraction of dust $<1.2 \mu \mathrm{m}$. 


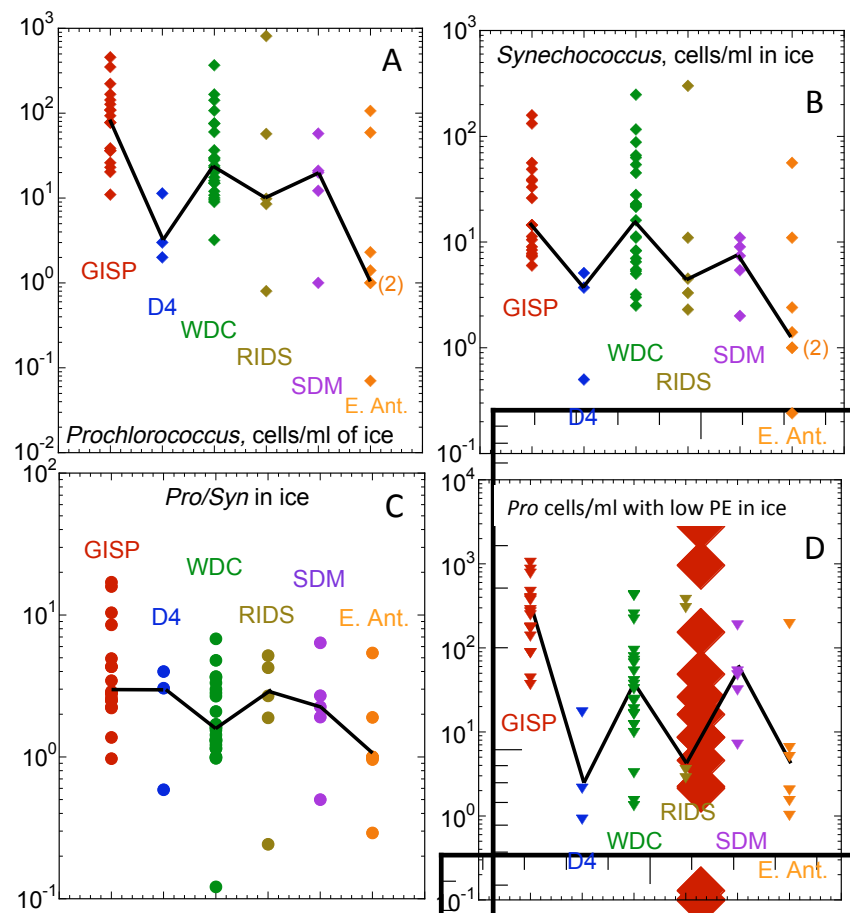

Fig. 9. Concentrations of cells from 8 different locations (including South Pole, Dome C and the US-Norway traverse in E. Antarctica), taking into account centrifuging and sample volume: (A) Pro-like: (B) Syn-like; (C) Pro-like / Syn-like; (D) Pro-like, but with low PE.

picocyanobacteria, we believe the most likely explanation for their presence at different sites and different depths in Arctic and Antarctic ice is aeolian transport from mid-latitude ocean waters within which concentrations up to $3 \times 10^{5}$ cells ml $^{-1}$ of Pro and a few $\times 10^{4}$ cells $\mathrm{ml}$ of Syn are typical in summer. The summer-winter shift in latitudes of the ocean temperature profiles would account for why the Chl and Trp autofluorescence measured with the BFS in scans along ice cores was often $\sim 25 \%$ higher at depths corresponding to local summers than at depths corresponding to local winters, as shown in Fig. 2. We confirmed the latitudinal shift of ocean temperatures by comparing National Oceanographic and Atmospheric Agency maps of global contours (http://www. osdpd.noaa.gov/data/sst/contour/global50.fi.gif) for sea surface temperature in January and July 2011 as representative of summer and winter in the two hemispheres. A second important factor is the increase in number of daylight hours during the season in which photosynthesis can take place. We attribute the decrease in Chl concentration and concentration of picocyanobacteria in ice from summer to winter to the combined effects of lower ocean temperature and fewer hours of daylight at latitudes populated by both Pro and Syn.

The above explanation for the annual modulation of $\mathrm{Chl}$ in ice is supported by the observation that the growth curve for cultures of Pro is much narrower in temperature than that of Syn (Moore et al., 1995). Pro MED4 and Pro
SS1120 grow only between $\sim 13^{\circ} \mathrm{C}$ and $\sim 28^{\circ} \mathrm{C}$, whereas Syn WH8102 grows at temperatures down to nearly $0^{\circ} \mathrm{C}$ and up to $\sim 34.5^{\circ} \mathrm{C}$. In order for both Pro and Syn to be present (Fig. 9) at all depths in Arctic and Antarctic ice and with a summer-winter concentration difference of only $\sim 25 \%$, they must have grown in waters at lower latitude and then been wind-borne from ocean surfaces to high-latitude polar regions, as we will discuss below. Doolittle et al. (2008) measured Pro concentrations and PE-rich picoplankton (Syn) concentrations vs. south latitude along a $2780-\mathrm{km}$ southnorth transect from Bouvetoya Island to Tristan da Cunha Island in the Atlantic sector of the Southern Ocean. They found $S y n$ cells in waters with temperature down to $1.3^{\circ} \mathrm{C}$, but found no Pro cells in waters below $\sim 12^{\circ} \mathrm{C}$. Zwirglmaier et al. (2008) found that Syn, but not Pro, were present at $72^{\circ} \mathrm{N}$ in the ocean between Svalbard and Norway. In his review of cyanobacteria in the polar regions, Vincent (2000a, b) reached a similar conclusion that in high-latitude waters Pro are missing whereas Syn are still present.

We discuss next how picocyanobacteria in temperate ocean waters are transported to the polar regions. It is now widely accepted that marine microbes are ejected into the atmosphere (Leck and Bigg, 2005) by wind shear, leading to production of bubbles, followed by bursting and ejection of their contents, including microbes, viruses, sea salt crystals and mucus-like matter. Both computer modeling and experiments have shown that aerosols consisting of volcanic ash, desert dust and microbes are frequently swept up by winds from surfaces and transported thousands of kilometres in the troposphere. Jaenicke (1980) calculated lifetimes of aerosols from ocean sources and desert sources separately. For ocean sources he calculated that aerosols with radii 0.01 to $10 \mu \mathrm{m}$ have a mean lifetime in the troposphere of $\sim 8$ days in winds with mean speed $\sim 10 \mathrm{~m} \mathrm{~s}^{-1}$. Stokes' Law dictates that the settling rate of atmospheric aerosols is proportional to radius squared and to excess of density above atmospheric density. Thus, microbial cells should take $\sim 30$ times as long to settle as would mineral dust of density $3.2 \mathrm{~g} \mathrm{~cm}^{-3}$ and typical radius $\sim 3$ times that of submicron-size cells. Picocyanobacterial cells can stay aloft for more than a month in the absence of rain and can reach polar ice from greater distances than would 2- $\mu \mathrm{m}$ mineral grains from deserts in Patagonia or China.

Studies of distributions of desert dust and volcanic ash particles in ice cores provide useful information on aeolian transport of marine microbes. Atmospheric circulation models show that many of the particles in the ice at Vostok Station were wind-blown from eruptions on Southern Hemisphere islands and spiraled southward and eastward onto Antarctica. Prospero et al. (2005) measured the seasonal flux of dust, bacteria and fungi that were wind-blown from Africa and caught on nets facing Africa. The bacteria and fungi were identified by their culturability, which showed that many of them remained alive in transit. Micron-size marine bacterial cells have been collected in airplanes at $5.4 \mathrm{~km}$ over 
the Southern Ocean (Posfai et al., 2003). Using a model of global atmospheric circulation (Schneider, 2006), Wilkinson et al. (2011) simulated dispersal of 9- $\mu \mathrm{m}$ microbes released from Tierra del Fuego. Within 10 days the microbes had spread over most of Antarctica.

As another example of comparative lifetimes in the troposphere, we compare the concentrations of salt and microbes in the Dome $C$ ice core: Sea salt crystals of diameter $0.8 \mu \mathrm{m}$ were diluted by a factor $\sim 10^{-6}$ from their concentration in the ocean to their present concentration $\sim 2 \times 10^{-8} \mathrm{~g} \mathrm{~g}^{-1}$ in Dome C ice (Wolff et al., 2006). According to our FCM data, Pro-like cells in Dome $\mathrm{C}$ ice were diluted by a factor $3 \times 10^{-6}$ from their abundance of $\sim 3 \times 10^{5}$ cells ml $^{-1}$ in the mid-latitude ocean to $\sim 1$ cell ml ${ }^{-1}$ in Dome $\mathrm{C}$ ice. After correcting for the six-fold faster rate of Stokes settling of $0.8 \mu \mathrm{m}$-diameter salt crystals of density 2.3 than of 0.5 $\mu \mathrm{m}$ Pro cells of density 1, the transport efficiencies of salt grains and Pro-like cells from oceans onto snow at Dome C are consistent with each other. Zeaxanthin, a carotenoid pigment in both Pro and Syn (Moore et al., 1995), provides two kinds of protection from UV in sunlight: it scavenges against UV-induced erythema and provides protection against reactive oxygen species.

\subsection{Long-term stability of $\mathrm{Chl}$ autofluorescence in ice}

Franklin et al. (2009) recently measured the average efficiency of Photosystem II in a population in which various fractions of phytoplankton cells had been deliberately heatkilled. For example, in their Fig. 1, when $50 \%$ had been rendered photosynthetically non-functional by heat-killing them and adding them to the population, the efficiency of PS II was measured to be surprisingly high, between $95 \%$ and $80 \%$ of the value in the absence of killed cells. In our present work, we discovered that when Pro-like and Syn-like cells were deposited onto snow and frozen into ice, FCM measurements of their Chl and PE per cell showed no detectable systematic decrease in autofluorescence with time, judging from comparison of the distributions of Chl vs. PE in FCM plots for Pro-like and Syn-like cells in very young GISP ice (60 yr at $19 \mathrm{~m})$ and in very old GISP ice (3037 m or $150000 \mathrm{yr})$, as shown in Fig. 7i-l. This is an example of a protective feature of glacial ice that preserves $\mathrm{Chl}$ and PE in phototrophs against losing autofluorescence intensity with time in total darkness. Protection against bleaching by sunlight during a several-day trip from mid-latitude to polar ice would be offered both by the coating of slime on cells lofted from ocean surfaces and by their zeaxanthin pigment.

\subsection{Phycoerythrin in Prochlorococcus cells}

Syn and the majority of cyanobacteria use phycobilisomes as light-harvesting antennas. Pro has evolved differently: it uses a divinyl Chl $a$ and divinyl Chl $b$ light-harvesting complex, as well as small amounts of PE (Olson et al., 1990; Scanlan et al., 2009), but no phycobilisomes. It has been found that all twelve genomes of recently sequenced isolates - six ecotypes that are high-light adapted (HL) and six that are low-light adapted (LL) - have lost the majority of genes involved in phycobilisome synthesis, and LL isolates retain six PE genes (cpeABSTYZ), whereas HL isolates have retained only the cpeB and cpeS PE genes (Kettler et al., 2007). The role of PE in Pro remains uncertain, but may be related to signal transduction rather than light harvesting (Steglich et al., 2003, 2005). For some years after its discovery it was thought that Pro exhibited only red fluorescence. Many older papers in the literature state that PE fluorescence is not detectable in Pro cells. Steglich et al. (2005) showed that Pro MED4 has a green-light absorbing PE that is more easily detected using excitation with a peak at $\sim 550 \mathrm{~nm}$ than the $488 \mathrm{~nm}$ light from an Ar laser, which most flow cytometers employ. Using our flow cytometer set at high PE gain, with careful attention to noise reduction and with excitation at $567 \mathrm{~nm}$ instead of $488 \mathrm{~nm}$, we were able to measure PE in picocyanobacterial cultures and in all the ice melts, as we demonstrated in Figs. 6 to 8. We emphasise that Pro-like cells in glacial ice exhibit $\mathrm{PE}$ autofluorescence that can be separated from noise. The points with red dots in those figures have low values of both $\mathrm{Chl}$ and PE consistent with their locations on FCM plots of Olson et al. (1990) and Scanlan et al. (2009) and in our cultures (Fig. 5). The numerous cells labelled with green dots in Figs. 6-8 have smaller PE concentrations than do the other Pro cells, but do scatter like Pro cells.

\subsection{Dependence of picocyanobacterial concentrations on climate in the last $150000 \mathrm{yr}$}

Krinner and Genthon (2003) modelled transit time for small particles to be blown from sources such as Patagonia to Antarctic sites where ice cores have been collected and analysed. For the present climate they found that transit times are shortest in southern winter, due to the more vigorous atmospheric circulation, and the concentration of particles reaching the sites is greater in winter relative to a fixed concentration of injected microbes. By contrast, our results in Fig. 2 show that the concentration of $\mathrm{Chl}$ in glacial ice, which we attribute mainly to picocyanobacteria transported from temperate ocean latitudes, is higher in local summer seasons. We conclude that modulation of concentrations at their sources dominates over modulation of transit times. Krinner and Genthon (2003) went on to compare modelled transit times for both the Last Glacial Maximum (21 kyr ago) and the time of inception of the last ice age ( $115 \mathrm{kyr}$ ago). They found that the transit time from Patagonia toward Antarctica was not significantly different from the present, which is consistent with our finding in Fig. 7 that the concentrations of Pro-like and Syn-like cells are similar in ice from both $19 \mathrm{~m}$ and $3037 \mathrm{~m}$. 


\subsection{Rejecting mineral grains}

In Sect. 4 and Fig. 2 we showed with the BFS that both Trp and $\mathrm{Chl}$ show intensity peaks in local summers. By contrast, the flux of mineral dust onto polar ice has an annual peak in local spring for Greenland (Svensson et al., 2000; Bory et al., 2002) and West Antarctica (McConnell et al., 2007), whereas Wegner (2008) found that dust flux was $\sim 3.5$ times higher in winter than in summer at Dronning Maud Land (E. Antarctica) during the Holocene and 7.6 times higher during the Glacial Period. Even if we were able to analyse ice only from depths corresponding to local summers, we would still have a substantial contamination of flow cytometer plots by dust grains unless we did one of two things: one would be to use a stain such as SYBR Green, which would show up cells both with and without $\mathrm{Chl}$ in them, but would reject mineral grains; the other would be not to stain them, but to trigger on a high enough level of $\mathrm{Chl}$ to reject both mineral grains and non-phototrophic microbes. In this study, we chose to focus on phototrophs and not use a stain.

\subsection{Prospects for a study of evolutionary changes in the genomes of picocyanobacterial cells before they are frozen in glacial ice}

For several reasons, the genomes of microbial cells do not continue to evolve after they are transported from ocean to ice: they are trapped as isolated cells in ice and, therefore, cannot undergo horizontal gene transfer; they do not have enough metabolic energy to grow (Price and Sowers, 2004); they cannot pass on their mutations to progeny; and their mutation rates decrease by several orders of magnitude simply from being at ice temperature instead of at ocean temperature. Furthermore, the following results of Tung et al. (2005) allow one to set an experimental upper limit less than $1 \mu \mathrm{m}$ per year $\left(10 \mathrm{~cm}\right.$ in $\left.10^{5} \mathrm{yr}\right)$ on the vertical distances bacteria travel in veins: at depths of $2054 \mathrm{~m}, 3018 \mathrm{~m}$ and $3036 \mathrm{~m}$ in GISP ice, they found a factor $\sim 10$ higher concentration of methanogens at depths within $10 \mathrm{~cm}$ of the depths of spikes of excess methane found by Ed Brook (unpublished results). They concluded that the excess methane had been generated by methanogens metabolising during more than $10^{5} \mathrm{yr}$ in the ice at a temperature of $-10^{\circ} \mathrm{C}$. Later Rohde et al. (2008) found spikes of excess Trp that they attributed at least in part to $\mathrm{N}_{2} \mathrm{O}$-producing microbes at the same depths in GISP ice where Sowers et al. (2003) had found narrow spikes of excess $\mathrm{N}_{2} \mathrm{O}$. Random walk of such microbes in veins would have broadened the spikes and smeared out the sharp agreement between depth of microbes and depth of their gas production.

One procedure would be to use single cell genomics to determine changes in the genome of one ecotype that is found to be common throughout an ice core. A more general procedure would be to analyse $16 \mathrm{~S}$ rDNA in ice at many depths in order to tease out evolutionary changes in picocyanobac- teria and other ecotypes with time and between oceans in the Northern and Southern Hemispheres.

\section{Conclusions}

We considered two possible sources of the picocyanobacteria that we studied in glacial ice from Arctic and Antarctic sites: (1) Picocyanobacteria in the marine polar environment are known to be rare, and Pro cells are absent. In their cultures and 16S rDNA analyses of picocyanobacteria in polar lakes, Vincent et al. (2000) found oxyphotobacteria they ascribed to the genera Synechococcus and Synechocystis and occasionally to phycoerythrin-rich isolates similar to $P$. marinus. The problem with this hypothetical source of picocyanobacteria throughout ice at all depths is that the total volume of polar lakes in the Arctic and Antarctic ice is extremely tiny,and the ratio of Pro-like to Syn-like cells is extremely low. (2) Pro and Syn cells in roughly the proportions we observed with FCM are carried by winds from oceans at temperate latitudes and could account for our observation of an annual summer/winter modulation. Although it is difficult to model accurately the fluxes of wind-borne Pro and Syn cells that reach the polar regions from mid-latitudes, we believe the second explanation is the more likely of the two.

We estimate that median DNA concentrations are $\sim 10^{2} \mathrm{pg}^{-1}$ in picocyanobacteria in West Antarctic and central Greenland ice and higher by an order of magnitude when all taxa are included. Increases in sensitivity and speed of analysis in genomics should make it possible to study bacterial evolution over $150000 \mathrm{yr}$ (corresponding to the age of ice from the greatest depth in central Greenland) as frozen proxies of their genomes in marine waters as a function of time. We have initiated a collaboration with Steve Giovannoni and Kevin Vergin (Oregon State University) and with Richard Lenski and Jeff Morris (Michigan State University) to identify marine bacteria as a function of depth in glacial ice and to study evolutionary changes in their genomes. H. Motoyama (National Institute of Polar Research, Japan) has authorised T. Segawa, a molecular biologist, to collaborate with us in future analyses of bacteria in the $3035 \mathrm{~m}$ Dome Fuji ice core. Depending on the microbial concentration and availability of large enough quantities of ice at the greatest depths in Dome Fuji, it may eventually be possible to extend the evolutionary study back $720000 \mathrm{yr}$ in time, equivalent to 300 million generations for genera with a generation time of 1 day), by analysing genomes of bacterial cells in ice from Dome Fuji (Motoyama, 2007).

Acknowledgements. We thank Nathan Bramall, Robert Rohde and Delia Tosi for construction, operation and analysis of data from the Berkeley Fluorescence Spectrometer; Steve Ruzin for training students in EFM and providing his live/dead stain; Hector Nolla for operating the Cytopeia Influx Sorter; students Tong Liu, Elaine Lee, Lisa Chen and Joyce Lee for laboratory 
assistance; and Dave Parks for advice on flow cytometry. We thank Kathryn Johnson for cultures of Pro and Syn, Kate Mackey for cultures of five strains of Syn, Alex Worden for cultures of Ostreo, Gustaf Arrhenius for grains of many minerals commonly found in ice cores, Chris McKay for volcanic ash, Mars soil simulant and Dry Valleys soil, the EPICA steering committee for providing ice from Dome $\mathrm{C}$, Joe McConnell for ice from the US-Norwegian traverse and Greenland site D4, Jeff Severinghaus for some WAIS Divide ice core samples, Bess Koffman for her data on particle distributions in the WAIS06A ice core, and the National Ice Core Laboratory staff for the other ice samples. Price thanks Lisa Moore, Alex Glazer, Kate Mackey, Eric Wolff, Alex Worden, Steve Giovannoni, Kevin Vergin, Richard Lenski, Jeffrey Morris, Takahiro Segawa and Hideaki Motoyama for discussions. Price and Bay acknowledge partial support from NSF Grants ANT-0738568 and ANT-1142178.

Edited by: K. Küsel

\section{References}

Anschütz, H., Sinisalo, A., Isaksson, E., McConnell, J. R., Hamran, S.-E., Bisiaux, M. M., Pasteris, D., Neumann, T. A., and Winther, J.-G.: Variation of accumulation rates over the last eight centuries on the East Antarctic Plateau derived from volcanic signals in ice cores, J. Geophys. Res., 116, D20103, doi:10.1029/2011JD015753, 2011.

Basile, I., Petit, J. R., Touron, S., Grousset, F. E., and Barkov, N.: Volcanic layers in Antarctic (Vostok) ice cores: source identification and atmospheric implications, J. Geophys. Res., 106, 31915-31931, 2001.

Bory, A., Biscaye, P. E., Svensson, A., and Grousset, F. E.: Seasonal variations of Asian dust composition in recent Greenland firn, Earth Planet. Sci. Lett., 196, 123-134, 2002.

Bramall, N. E.: The remote sensing of microorganisms, Ph.D. thesis, Physics, University of California, Berkeley, CA, 1-223, (unpublished), 2007.

Bramall, N. E., Bay, R. C., Woschnagg, K., Rohde, R. A., and Price, P. B.: A deep high-resolution optical log of dust, ash, and stratigraphy in South Pole glacial ice, Geophys. Res. Lett., 32, L21815, doi:10.1029/2005GL024236, 2005.

Chance, B., Cohen, P., Joksis, F., and Schoener, B.: Intracellular oxidation-reduction states in vivo, Science, 137, 449-508, 1962.

Chisholm, S. W., Olson, R. J., Zettler, E. R., Goericke, R., Waterbury, J. B., and Welschmeyer, N. A: A novel free living prochlorophyte abundant in the oceanic euphotic zone, Nature, 334, 340-343, 1988.

Christner, B. C., Kvitko, B. H., and Reeve, J. N.: Molecular identification of Bacteria and Eukarya inhabiting an Antarctic cryoconite hole, Extremophiles, 7, 177-183, 2003.

Cole-Dai, J., Budner, D. M., and Ferris, D. G.: High speed, high resolution, and continuous chemical analysis of ice cores using a melter and ion chromatography, Environ. Sci. Technol., 40, 6764-6769, 2006.

D'Elia, T., Veerapaneni, R., Theraisnathan, V., and Rogers, S. O.: Isolation of fungi from Lake Vostok accretion ice, Mycologia, 101, 751-763, 2009.

Doolittle, D. F., Li, W. K. W., and Wood, A. M.: Wintertime abundance of picoplankton in the Atlantic sector of the Southern
Ocean, Nova Hedwigia, 133, 147-160, 2008.

Dufresne, A., Salanoubat, M., Partensky, F., Artiguenave, F., Axmann, I. M., Barbe, V., Duprat, S., Galperin, M. Y., Koonin, E. V., Le Gall, F., Makarova, K. S., Ostrowski, M., Oztas, S., Robert, C., Rogozin, I. B., Scanlan, D. J., Tandeau de Marsac, N., Weissenbach, J., Wincker, P., Wolf, Y. I., and Hess, W. R.: Genome sequence of the cyanobacterium Prochlorococcus marinus SS120, a nearly minimal oxyphototrophic genome, P. Natl. Acad. Sci. USA, 100, 10020-10025, 2003.

Franklin, D. J., Choi, C. J., Hughes, C., Malin, G., and Berges, J. A.: Effect of dead phytoplankton cells on the apparent efficiency of photosystem II, Mar. Ecol. Prog. Ser., 382, 35-40, 2009.

French, C. S., Smith, J. H. C., Virgin, H. I., and Airth, R. L.: Fluorescence-spectrum curves of chlorophylls, pheophytins, phycoerythrins, phycocyanins and hypericin, Plant. Physiol., 31, 369-374, 1956.

Gregg, W. W.: Assimilation of SeaWiFS ocean chlorophyll data into a three-dimensional global ocean model, J. Marine Syst., 69, 205-225, 2008.

Jaenicke, R.: Atmospheric aerosols and global climate, J. Aerosol Sci., 11, 577-588, 1980.

Kettler, G. C., Martiny, A. C., Huang, K., Zucker, J., Coleman, M. L., Rodrigue, S., Chen, F., Lapidus, A., Ferriera, S., Johnson, J., Steglich, C., Church, G. M., Richardson, P., and Chisholm, S. W.: Patterns and implications of gene gain and loss in the evolution of Prochlorococcus, PLoS Genetics, 3, 2515-2528, 2007.

Koffman, B. G., Kreutz, K. J., and Mahowald, N. M.: Changes in atmospheric circulation over the past $2400 \mathrm{yr}$ inferred from the WAIS Divide ice core dust record, Proceedings Eighth International Symposium on Microbial Ecology, in preparation, 2012.

Krinner, G. and Genthon, C.: Troposphere transport of continental tracers towards Antarctica under varying climatic conditions, Tellus, 55B, 54-70, 2003.

Kurbatov, A. V., Zielinski, G. A., Dunbar, N. W., Mayewski, P. A., Meyerson, E. A., Sneed, S. B., and Taylor, K. C.: A 12000 year record of explosive volcanism in the Siple Dome ice core, West Antarctica, J. Geophys. Res., 111, D12307, doi:10.1029/2005JD006072, 2006.

Lambert, F., Delmonte, B., Petit, J. R., Bigler, M., Kaufmann, P. R., Hutterli, M. A., Stocker, T. F., Ruth, U., Steffensen, J. P., and Maggi, V.: Dust-climate couplings over the past 800000 years from the EPICA Dome C ice core, Nature, 452, 616-619, 2008.

Leck, C. and Bigg, E. K.: Biogenic particles in the surface microlayer and overlaying atmosphere in the central Arctic Ocean during summer, Tellus, 57B, 305-316, 2005.

Li, F., Ginoux, P., and Ramaswamy, V.: Distribution, transport, and deposition of mineral dust in the Southern Ocean and Antarctica: Contributions of major sources, J. Geophys. Res., 113, D10207, doi:10.1029/2007JD009190, 2008.

Marie, D., Partensky, F., Vaulot, D., and Brussaard, C.: Enumeration of phytoplankton, bacteria, and viruses in marine samples, Current Protocols in Cytometry, Suppl., 10, 11.1-11.15, 1999.

McConnell, J. R., Aristarain, A. J., Banta, J. R., Edwards, P. R., and Simões, J. C.: 20th-century doubling in dust archived in an Antarctic Peninsula ice core parallels climate change and desertification in South America, P. Natl. Acad. Sci. USA, 104, 57435748, 2007.

Miteva, V.: Bacteria in snow and glacier ice, Ch. 3, Psychrophiles, in: Biodiversity to biotechnology, edited by: Margesin, R., 
Springer-Verlag, Berlin, Heidelberg, 2008.

Miteva, V. I. and Brenchley, J. E.: Detection and isolation of ultrasmall microorganisms from a 120000-year-old Greenland glacier ice core, Appl. Environ. Microbiol., 71, 7806-7818, 2005.

Moore, L. R., Goericke, R., and Chisholm, S. W.: Comparative physiology of Synechococcus and Prochlorococcus: influence of light and temperature on growth, pigments, fluorescence and absorptive properties, Mar. Ecol. Prog. Ser., 116, 259-275, 1995.

Motoyama, H.: The second deep ice coring project at Dome Fuji, Antarctica, Scientific Drilling, 5, 41-43, doi:10.2204/iodp.sd.5.05.2007, 2007.

Olson, R. J., Chisholm, S. W., Zettler, E. R., Altabet, M. A., and Dusenberry, A.: Spatial and temporal distributions of prochlorophyte picoplankton in the North Atlantic ocean, Deep-Sea Res., 37, 1033-1039, 1990.

Palenik, B., Brahamsha, B., Larimer, F. W., Land, M., Hauser, L., Chain, P., Lamerdin, J., Regala, W., Allen, E. E., McCarren, J., Paulsen, I., Dufresne, A., Partensky, F., E. A. Webb, E. A., and Waterbury, J.: The genome of a motile marine Synechococcus, Nature, 424, 1037-1041, 2003.

Posfai, M., Li, J., Anderson, J. R., and Buseck, P. R.: Aerosol bacteria over the Southern Ocean during ACE-1, Atm. Res., 66, 231240, 2003.

Powell, L. M., Bowman, J. P., Skerratt, J. H., Franzmann, P. D., and Burton, H. R.: Ecology of a novel Synechococcus clade occurring in dense populations in saline Antarctic lakes, Mar. Ecol. Prog. Ser., 291, 65-80, 2005.

Price, P. B.: A habitat for psychrophiles in deep Antarctic ice, Proc. Natl. Acad. Sci. USA, 97, 1247-1251, 2000.

Price, P. B.: Minireview: Microbial life in glacial ice and implications for a cold origin of life, FEMS, Microbiol. Ecol., 59, 217231, 2007.

Price, P. B.: Low temperature limits of microbial growth and metabolism, Chap. 12, in: Polar Microbiology: Life in a Deepfreeze, edited by: Miller, R. and Whyte, L. G., ASM Press, Washington DC, 2012.

Price, P. B. and Sowers, T.: Temperature dependence of metabolic rates for microbial growth, maintenance, and survival, P. Natl. Acad. Sci. USA, 101, 4632-4636, 2004.

Price, P. B., Rohde, R. A., and Bay, R. C.: Fluxes of microbes, organic aerosols, dust, sea-salt $\mathrm{Na}$ ions, non-sea-salt $\mathrm{Ca}$ ions, and methanesulfonate onto Greenland and Antarctic ice, Biogeosciences, 6, 479-486, doi:10.5194/bg-6-479-2009, 2009.

Priscu, J. C. and Christner, B. C.: Earth's icy biosphere, in: Microbial Diversity and Bioprospecting, edited by: Bull, A. T., ASM Press, Washington DC, USA, 130-145, 2004.

Prospero, J. M., Blades, E., Mathison, G., and Naidu, R.: Interhemispheric transport of viable fungi and bacteria from Africa to the Caribbean with soil dust, Aerobiologia, 21, 1-19, 2005.

Rocap, G., Larimer, F. W., Lamerdin, J., Malfatti, S., Chain, P., Ahlgren, N. A., Arellano, A., Coleman, M., Hauser, L., Hess, W. R., Johnson, Z. I., Land, M., Lindell, D., Post, A. F., Regala, W., Shah, M., Shaw, S. L., Steglich, C., Sullivan, M. B., Ting, C. S., Tolonen, A., Webb, E. A., Zinser E. R., and Chisholm, S. W.: Genome divergence in two Prochlorococcus ecotypes reflects oceanic niche differentiation, Nature, 424, 1042-1047, 2003.

Rohde, R. A.: The development and use of the Berkeley Fluorescence Spectrometer to characterise microbial content and detect volcanic ash in glacial ice, Ph.D. thesis, Physics, University of California, Berkeley, CA, 2009.

Rohde, R. A. and Price, P. B.: Diffusion-controlled metabolism for long-term survival of single isolated microorganisms trapped within ice crystals, P. Natl. Acad. Sci. USA, 104, 16592-16597, 2007.

Rohde, R. A., Price, P. B., Bay, R. C., and Bramall, N. E.: In situ microbial metabolism as a cause of gas anomalies in ice, P. Natl. Acad. Sci. USA, 105, 8667-8672, 2008.

Ruth, U., Wagenbach, D., Steffensen, J. P., and Bigler, M.: Continuous record of microparticle concentration and size distribution in the central Greenland NGRIP ice core during the last glacial period, J. Geophys. Res., 108, 4098, doi:10.1029/2002JD002376, 2003.

Scanlan, D. J., Ostrowski, M., Mazard, S., Dufresne, A., Garczarek, L., Hess, W. R., Post, A. F., Hagemann, M., Paulsen, I., and Partensky, F.: Ecological genomics of marine picocyanobacteria, Microbiol. Mol. Biol. Rev., 73, 249-299, 2009.

Schneider, T.: The general circulation of the atmosphere, Annu. Rev. Earth Planet. Sci., 34, 655-688, 2006.

Sowers, T., Alley, R. B., and Jubenville, J.: Ice core records of atmospheric $\mathrm{N}_{2} \mathrm{O}$ covering the last 106000 years, Science, 301, 945-948, 2003.

Steglich, O., Mullineaux, C. W., Teuchner, K., Hess, W. R., and Lokstein, H.: Photophysical properties of Prochlorococcus marinus SS120 divinyl chlorophylls and phycoerythrin in vitro and in vivo, FEBS Lett., 553, 79-84, 2003.

Steglich, C., Frankenburg-Dinkel, N., Penno, S., and Hess, W. R.: A green light-absorbing phycoerythrin is present in the high-lightadapted marine cyanobacterium Prochlorococcus sp. Med4, Environ. Microbiol., 7, 1611-1618, 2005.

Svensson, A., Biscaye, P. E., and Grousset, F. E.: Characterization of late glacial continental dust in the Greenland Ice Core Project ice core, J. Geophys. Res., 105, 4637-4656, 2000.

Tung, H. C., Bramall, N. E., and Price, P. B.: Microbial origin of excess methane in glacial ice and implications for life on Mars, P. Natl. Acad. Sci. USA, 102, 18292-18296, 2005.

Vincent, W. F.: Cyanobacterial dominance in the polar regions, $\mathrm{Ch}$. 12, in: The Ecology of Cyanobacteria, edited by: Whitton, B. A. and Potts, M., Kluwer Academic Publishers, Netherlands, 321340, 2000a.

Vincent, W. F.: Phylogenetic diversity of picocyanobacteria in Arctic and Antarctic ecosystems, in: Proc. 8th Intern. Symposium on Microbial Ecology, edited by: Bell, C. R., Brylinsky, M., and Johnson-Green, P., Atlantic Canada Society for Microbial Ecology, Halifax, Canada, 321-340, 2000b.

Walker, T. D. and Marchant, H. J.: The seasonal occurrence of chroococcoid cyanobacteria at an Antarctic coastal site, Polar Biol., 9, 193-196, 1989.

Wegner, A.: Sources and transport characteristics of mineral dust in Dronning Maud Land, Antarctica, Ph.D. Dissertation, University of Bremen, Germany, 2008.

Wilkinson, D. M., Koumoutsaris, S., Mitchell, E. A. D., and Bey, I.: Modeling the effect of size on the aerial dispersal of microorganisms, J. Biogeogr., 38, 1-9, 2011.

Wolff, E. W., Fischer, H., Fundel, F., Ruth, U., Twarloh, B., Littot, G. C., Mulvaney, R., Rothlisberger, R., de Angelis, M., Boutron, C. F., Hansson, M., Jonsell, U., Hutterli, M. A., Lambert, F., Kaufmann, P., Stauffer, B., Stocker, T. F., Steffensen, J. P., Bigler, 
M., Siggaard- Andersen, M. L., Udisti, R., Becagli, S., Castellano, E., Severi, M., Wagenbach, D., Barbante, C., Gabrielli, P., and Gaspari, V.: Southern Ocean sea-ice extent, productivity and iron flux over the past eight glacial cycles, Nature, 440, 491-496, 2006.

Worden, A. Z., Nolan, J. K., and Palenik, B.: Assessing the dynamics and ecology of marine picophytoplankton: the importance of the eukaryotic component, Limnol. Oceanogr., 49, 168-179, 2004.

Zwirglmaier, K., Jardillier, L., Ostrowski, M., Mazard, S., Garczarek, L., Vaulot, D., Not, F., Massana, R., Ulloa, O., and Scanlan, D.: Global phylogeography of marine Synechococcus and Prochlorococcus reveals a distinct partitioning among oceanic biomes, Environ. Microbiol., 10, 147-161, 2008. 